\title{
Factors Influencing Labor Productivity in Modern Economies: A Review and Qualitative Text Analysis
}

\author{
MARIUSZ-JAN RADŁO, ARTUR F. TOMECZEK \\ Global Economic Interdependence Department, Collegium of World Economy \\ SGH Warsaw School of Economics \\ al. Niepodległości 162, 02-554 Warsaw \\ POLAND
}

\begin{abstract}
We conduct a semi-systematic literature review and a qualitative text analysis of 141 publications on labor productivity. We have identified 12 factors that play a leading role in economic research of labor productivity: (i) agglomerations effect; (ii) business cycles and market selection; (iii) cross-country institutional differences; (iv) environmental aspects; (v) foreign direct investment (FDI); (vi) globalization and international trade; (vii) global value chains (GVC); (viii) human capital; (ix) information and communications technology (ICT); (x) labor allocation; (xi) R\&D and innovation; (xii) regional differences. When it comes to the quotes count, the most prominent factor is (xi) R\&D, followed by (vi) globalization and (viii) human capital. When it comes to the co-occurrence and c-coefficient, the most prominent factor is (viii) human capital, closely followed by (i) agglomerations, then either (xi) R\&D or (vi) globalization. Network analysis reveals two communities, the bigger one centered around (i) agglomerations, and the smaller one centered around (vi) globalization.
\end{abstract}

Key-Words: labor productivity, factors of productivity, qualitative text analysis, network analysis, literature review, bibliometric analysis

Received: June 27, 2021. Revised: December 27, 2021. Accepted: January 12, 2022. Published: February 4, 2022.

\section{Introduction}

Labor productivity is one of the tenets of mainstream economic theory. For decades it has been at the forefront of academic research, yet its relevance remains as high as ever. It is also futureproof, as even in a robot-dominated workplace environment there will still be labor productivity to be measured - albeit of a different kind. With a subject so broad and important it is worthwhile to systematize and predict the direction the specific research field is going to take - and the following review and qualitative text analysis represent our attempt to provide that.

\section{Methodology}

The aim of this article is twofold. First, we want to identify the factors that influence labor productivity in modern economies. Second, an attempt is made to create an original theoretical framework for future empirical research. To fulfill the abovementioned research aims, we put forward three research questions: [RQ1] What are the key recent insights in the literature? [RQ2] Are there significant themes in the literature? [RQ3] Which factor is the most prominent in the literature?
No single theoretical study can capture every single topic in the history of labor productivity. However, we believe that the factors identified in our research are crucial for understanding the changes in labor productivity in modern economies. The categories proposed by us have been identified as important factors during the initial review process and word count analysis of collected publications and confirmed as such through a more in-depth qualitative study. Initially, we had identified 42 potential topics that we later combined into 12 categories used throughout this article (see: Table 1).

The primary research methods used in this article are literature review, bibliometric analysis, and qualitative text analysis. Following the methodology of Snyder [1] and motivated by the overwhelming number of publications on the broad topic of our research, we have adapted a semisystematic approach to the literature review. Bibliometric analysis is rather brief and conducted entirely using the Web of Science analyzing tool. Furthermore, for the qualitative text analysis, we utilize a computer-assisted qualitative data analysis using Atlas.ti software. Following Kuckartz's [2] methodology, we chose a thematic qualitative text analysis with quantitative elements. Finally, there 
are several network views constructed using Gephi software. The qualitative text analysis is based on the concepts of codes and sub-codes which are described in detail in section four.

Analyzed scientific papers mostly concern more than one issue, for example, it is hard to imagine research about the impact of agglomerations that disregards the role of human capital. This intuitive interdependence will be put to test during the qualitative text analysis. As such, for the sake of clearness, each paper has been assigned to only one category that best describes its subject matter. The literature was collected using the Google Scholar bibliometric database (general search term of "labor OR labour productivity") with a supplementary search conducted in the Web of Science bibliometric database. The primary criteria of inclusion were relevance to the topic, language (only publications in English), timeliness (how recent is the research), and the importance of the paper (measured by the number of citations in Google Scholar). Some subjective judgments were necessary for the selection of the literature due to the overwhelming number of publications on this topic. The exclusion of literature not in English is motivated by the computer-assisted qualitative data analysis, which would be much more complicated in multiple languages. Future research could explore potential differences present in qualitative text analyses conducted in different languages. There is a small number of works cited in this article that play a supporting role (e.g. methodological context), which are not included in the 141 publications utilized in the qualitative text analysis.

During the course of the literature review, we have divided the selected analyzed papers $(n=141)$ into 12 categories: (i) agglomerations effect; (ii) business cycles and market selection; (iii) crosscountry institutional differences; (iv) environmental aspects; (v) foreign direct investment (FDI); (vi) globalization and international trade; (vii) global value chains (GVC); (viii) human capital; (ix) information and communications technology (ICT); (x) labor allocation; (xi) R\&D and innovation; (xii) regional differences.

Table 2 shows the simplified versions of codes used in the auto-coding process of the qualitative text analysis. The results were manually revised.

Table 1. Initial categories/themes identified during literature review

\begin{tabular}{|c|c|c|c|}
\hline Initial & $\begin{array}{c}\text { Fina } \\
\mathbf{l}\end{array}$ & Initial & $\begin{array}{c}\text { Fina } \\
\mathbf{l}\end{array}$ \\
\hline aging workforce & (viii) & ICT-intensive & (ix) \\
\hline
\end{tabular}

\begin{tabular}{|c|c|c|c|}
\hline Initial & $\begin{array}{c}\text { Fina } \\
1\end{array}$ & Initial & $\begin{array}{c}\text { Fina } \\
1\end{array}$ \\
\hline & & sectors/ICT & \\
\hline agglomerations & (i) & infrastructure & (viii) \\
\hline agriculture sector & $\begin{array}{c}\text { vario } \\
\text { us }\end{array}$ & innovation & (xi) \\
\hline broadband access & (ix) & $\begin{array}{l}\text { intangible } \\
\text { investment }\end{array}$ & (xi) \\
\hline business cycles & (ii) & $\begin{array}{c}\text { internal economies } \\
\text { of scale }\end{array}$ & (x) \\
\hline $\begin{array}{c}\text { climate } \\
\text { change/environm } \\
\text { ent }\end{array}$ & (iv) & international M\&A & (vi) \\
\hline $\begin{array}{c}\text { construction } \\
\text { sector }\end{array}$ & (viii) & labor allocation & $(\mathrm{x})$ \\
\hline convergence & (xii) & labor mobility & $(\mathrm{x})$ \\
\hline $\begin{array}{c}\text { countercyclical } \\
\text { behavior }\end{array}$ & (ii) & $\begin{array}{c}\text { labor } \\
\text { unions/privatization }\end{array}$ & $(\mathrm{x})$ \\
\hline $\begin{array}{l}\text { employment } \\
\text { density }\end{array}$ & (i) & liberalization & (vi) \\
\hline employment type & (x) & $\begin{array}{l}\text { manufacturing } \\
\text { sector }\end{array}$ & $\begin{array}{c}\text { vario } \\
\text { us }\end{array}$ \\
\hline exchange rate & (iii) & $\begin{array}{c}\text { motivational } \\
\text { factors/morale/HR } \\
\text { management }\end{array}$ & (viii) \\
\hline $\begin{array}{c}\text { export/internation } \\
\text { al trade }\end{array}$ & (vi) & outsourcing & (vi) \\
\hline FDI & (v) & pollution & (iv) \\
\hline financial crisis & (ii) & $\begin{array}{l}\text { production } \\
\text { specialization }\end{array}$ & (iii) \\
\hline firm's lifecycle & (ii) & $\mathrm{R} \& \mathrm{D}$ & (xi) \\
\hline globalization & (vi) & regional differences & (xii) \\
\hline $\begin{array}{c}\text { government } \\
\text { expenditure/publi } \\
\text { c policies }\end{array}$ & (viii) & services & $\begin{array}{c}\text { vario } \\
\text { us }\end{array}$ \\
\hline GVC & (vii) & $\begin{array}{c}\text { theoretical } \\
\text { descriptions of } \\
\text { methods }\end{array}$ & $\begin{array}{c}\text { vario } \\
\text { us }\end{array}$ \\
\hline health & (viii) & $\begin{array}{c}\text { vertical } \\
\text { specialization }\end{array}$ & (vii) \\
\hline $\begin{array}{c}\text { human } \\
\text { capital/education } \\
\text { quality } \\
\end{array}$ & (viii) & violence/crime & (viii) \\
\hline
\end{tabular}

Source: Own preparation.

Table 2. Simplified codes for the qualitative text analysis (codes include themselves and their every sub-code)

\begin{tabular}{|c|c|}
\hline Code/sub-code & Coding keywords \\
\hline AGGLOMERATIONS & AGGLOMERATION|CITY|URBAN \\
\hline $\begin{array}{l}\text { AGGLOMERATIONS: } \\
\text { Congestion }\end{array}$ & $\begin{array}{c}\text { congestion|traffic } \\
\text { jam|commute|gridlock|overcrowding }\end{array}$ \\
\hline $\begin{array}{l}\text { AGGLOMERATIONS: } \\
\text { Employment density }\end{array}$ & employment density \\
\hline $\begin{array}{l}\text { AGGLOMERATIONS: } \\
\text { Spillovers }\end{array}$ & spillover \\
\hline BUSINESS CYCLES & BUSINESS CYCLE \\
\hline $\begin{array}{l}\text { BUSINESS CYCLES: } \\
\text { Crisis }\end{array}$ & $\begin{array}{l}\text { crisis|economic downturn|economic } \\
\text { collapse|market crash|bubble burst }\end{array}$ \\
\hline $\begin{array}{l}\text { BUSINESS CYCLES: } \\
\text { Employment (total) }\end{array}$ & total employment|labor force \\
\hline $\begin{array}{l}\text { BUSINESS CYCLES: } \\
\text { Market selection }\end{array}$ & $\begin{array}{l}\text { market selection|market forces|market } \\
\text { failure|reallocation of resources }\end{array}$ \\
\hline $\begin{array}{l}\text { BUSINESS CYCLES: } \\
\text { Procyclicality }\end{array}$ & procyclicality|cyclicality \\
\hline $\begin{array}{c}\text { COUNTRY } \\
\text { DIFFERENCES }\end{array}$ & $\begin{array}{c}\text { COUNTRY } \\
\text { DIFFERENCES|NATIONAL } \\
\text { DIFFERENCES } \\
\end{array}$ \\
\hline $\begin{array}{c}\text { COUNTRY } \\
\text { DIFFERENCES: Country } \\
\text { specialization }\end{array}$ & $\begin{array}{c}\text { country specialization|specialized } \\
\text { economies|comparative } \\
\text { advantage|absolute advantage|localized } \\
\text { productivity }\end{array}$ \\
\hline
\end{tabular}




\begin{tabular}{|c|c|}
\hline Code/sub-code & Coding keywords \\
\hline $\begin{array}{l}\text { COUNTRY } \\
\text { DIFFERENCES: } \\
\text { Institutions }\end{array}$ & institution|institutional \\
\hline $\begin{array}{c}\text { COUNTRY } \\
\text { DIFFERENCES: Relative } \\
\text { prices }\end{array}$ & relative prices|comparative prices \\
\hline ENVIRONMENT & ENVIRONMENT|ENVIRONMENTAL \\
\hline $\begin{array}{l}\text { ENVIRONMENT: Air } \\
\text { pollution }\end{array}$ & $\begin{array}{l}\text { air pollution|air contamination|lung } \\
\text { disease|lung cancer|asthma|toxic } \\
\text { particles|fine particles|particulate matter }\end{array}$ \\
\hline $\begin{array}{l}\text { ENVIRONMENT: } \\
\text { Climate change }\end{array}$ & $\begin{array}{c}\text { climate change|climate warming|global } \\
\text { warming }\end{array}$ \\
\hline $\begin{array}{l}\text { ENVIRONMENT: Green } \\
\text { investment }\end{array}$ & $\begin{array}{c}\text { green investment|eco } \\
\text { investment|responsible } \\
\text { investment|sustainable } \\
\text { investment|ecological } \\
\text { investment|environmental regulation }\end{array}$ \\
\hline FDI & FDI|Foreign direct investment \\
\hline FDI: Investment policy & $\begin{array}{l}\text { investment policy|FDI policy|Foreign } \\
\text { direct investment policy|FDI } \\
\text { policies|Foreign direct investment } \\
\text { policies|investment policies }\end{array}$ \\
\hline FDI: Inward FDI & $\begin{array}{c}\text { inward FDI| FDI inflow|investment } \\
\text { inflow|incoming investment|FDI } \\
\text { host|incoming FDI|iFDI }\end{array}$ \\
\hline FDI: Outward FDI & $\begin{array}{c}\text { outward FDI|FDI outflow|investment } \\
\text { outflow|outgoing investment|outgoing } \\
\text { FDI|oFDI }\end{array}$ \\
\hline GLOBALIZATION & $\begin{array}{c}\text { GLOBALIZATION|INTERNATIONALI } \\
\text { ZATION } \\
\end{array}$ \\
\hline $\begin{array}{l}\text { GLOBALIZATION: } \\
\text { Financial liberalization }\end{array}$ & $\begin{array}{c}\text { financial liberalization|financial } \\
\text { integration|capital flows|capital market } \\
\text { liberalization }\end{array}$ \\
\hline $\begin{array}{l}\text { GLOBALIZATION: } \\
\text { Outsourcing }\end{array}$ & outsourcing|offshoring \\
\hline $\begin{array}{l}\text { GLOBALIZATION: } \\
\text { Trade }\end{array}$ & trade \\
\hline $\begin{array}{l}\text { GLOBALIZATION: } \\
\text { Trade liberalization }\end{array}$ & $\begin{array}{l}\text { trade liberalization|free trade|free } \\
\text { market|trade integration }\end{array}$ \\
\hline $\begin{array}{l}\text { GLOBALIZATION: } \\
\text { Transnational } \\
\text { corporations }\end{array}$ & $\begin{array}{c}\text { transnational } \\
\text { corporations|TNC|multinational } \\
\text { corporations|MNC|international } \\
\text { firm|multinational } \\
\text { enterprise|MNE|transnational } \\
\text { enterprise|multinationals }\end{array}$ \\
\hline HUMAN CAPITAL & HUMAN CAPITAL \\
\hline $\begin{array}{l}\text { HUMAN CAPITAL: } \\
\text { Education }\end{array}$ & education|schooling|scholarship|academic \\
\hline $\begin{array}{l}\text { HUMAN CAPITAL: } \\
\text { Health } \\
\end{array}$ & $\begin{array}{l}\text { health|disease|caloric } \\
\text { intake|nutrition|vaccine }\end{array}$ \\
\hline $\begin{array}{l}\text { HUMAN CAPITAL: } \\
\text { Healthcare }\end{array}$ & $\begin{array}{c}\text { healthcare|medical } \\
\text { personnel|medics|nurse|medical } \\
\text { doctor|hospital|clinic } \\
\end{array}$ \\
\hline $\begin{array}{l}\text { HUMAN CAPITAL: } \\
\text { Knowledge } \\
\end{array}$ & knowledge|know-how \\
\hline $\begin{array}{l}\text { HUMAN CAPITAL: Life } \\
\text { expectancy }\end{array}$ & life expectancy|life span|lifespan \\
\hline ICT & $\begin{array}{c}\text { ICT|Information and Communications } \\
\text { Technology }\end{array}$ \\
\hline ICT: ICT capital & $\begin{array}{l}\text { ICT capital|Information Technology } \\
\text { capital|computers }\end{array}$ \\
\hline $\begin{array}{l}\text { ICT: ICT intensive } \\
\text { industry }\end{array}$ & $\begin{array}{l}\text { ICT intensive industry|IT intensive } \\
\text { industry|ICT related industry|ICT firm }\end{array}$ \\
\hline ICT: ICT investment & $\begin{array}{c}\text { ICT investment|IT investment|computer } \\
\text { investment|ICT expenditure }\end{array}$ \\
\hline ICT: Internet & Internet|world wide web|broadband|Wi-Fi \\
\hline LABOR ALLOCATION & LABOR ALLOCATION \\
\hline $\begin{array}{l}\text { LABOR ALLOCATION: } \\
\text { Employment type }\end{array}$ & $\begin{array}{c}\text { employment type|seasonal } \\
\text { employment|part-time|seasonal } \\
\text { work|formal employment|informal } \\
\text { employment|temporary employment }\end{array}$ \\
\hline $\begin{array}{l}\text { LABOR ALLOCATION: } \\
\text { Labor market } \\
\end{array}$ & labor market \\
\hline
\end{tabular}

\begin{tabular}{|c|c|}
\hline Code/sub-code & Coding keywords \\
\hline $\begin{array}{l}\text { LABOR ALLOCATION: } \\
\text { Labor mobility }\end{array}$ & labor mobility \\
\hline $\begin{array}{c}\text { LABOR ALLOCATION: } \\
\text { Migration }\end{array}$ & migration|emigration|immigration \\
\hline $\begin{array}{l}\text { LABOR ALLOCATION: } \\
\text { Worker reallocation }\end{array}$ & $\begin{array}{l}\text { worker reallocation|retraining program|job } \\
\text { change|employment change|labor } \\
\text { reallocation }\end{array}$ \\
\hline R\&D & $\begin{array}{c}\text { R\&D|research and development|research } \\
\text { \& development }\end{array}$ \\
\hline R\&D: Innovation & Innovation|innovative \\
\hline $\begin{array}{l}\text { R\&D: Intangible } \\
\text { investment }\end{array}$ & $\begin{array}{c}\text { Intangible investment|intellectual } \\
\text { property|intellectual } \\
\text { properties|intangibles|intangible capital }\end{array}$ \\
\hline R\&D: Process innovation & process innovationlinnovative process \\
\hline R\&D: Product innovation & product innovation|innovative product \\
\hline R\&D: R\&D expenditure & $\begin{array}{c}\text { R\&D expenditure|expenditure on } \\
\text { R\&D|research expenditure|research and } \\
\text { development expenditure }\end{array}$ \\
\hline R\&D: R\&D intensity & $\begin{array}{l}\text { R\&D intensity|research and development } \\
\text { intensity|research intensity }\end{array}$ \\
\hline $\begin{array}{l}\text { REGIONAL } \\
\text { DIFFERENCES }\end{array}$ & $\begin{array}{l}\text { REGIONAL DIFFERENCES|high- } \\
\text { productivity regions|productive } \\
\text { region|regional growth|high-growth } \\
\text { region|specialized region }\end{array}$ \\
\hline $\begin{array}{l}\text { REGIONAL } \\
\text { DIFFERENCES: Beta } \\
\text { convergence }\end{array}$ & beta convergence $\mid \beta$-convergence \\
\hline $\begin{array}{l}\text { REGIONAL } \\
\text { DIFFERENCES: } \\
\text { Convergence }\end{array}$ & convergence \\
\hline $\begin{array}{c}\text { REGIONAL } \\
\text { DIFFERENCES: } \\
\text { Geographic location }\end{array}$ & $\begin{array}{c}\text { geographic } \\
\text { location|North|South|West|East }\end{array}$ \\
\hline $\begin{array}{l}\text { REGIONAL } \\
\text { DIFFERENCES: Sigma } \\
\text { convergence }\end{array}$ & sigma convergence $\mid \sigma$-convergence \\
\hline GVC & GLOBAL VALUE CHAINS|GVC \\
\hline GVC: Upstream activities & $\begin{array}{c}\text { upstream activities|upstreamness|upstream } \\
\text { flow|upstream stages }\end{array}$ \\
\hline $\begin{array}{l}\text { GVC: Downstream } \\
\text { activities }\end{array}$ & $\begin{array}{c}\text { downstream } \\
\text { activities|downstreamness|downstream } \\
\text { flow|downstream stages }\end{array}$ \\
\hline GVC: Vertical integration & $\begin{array}{c}\text { vertical integration|vertical } \\
\text { specialization|vertically specialized }\end{array}$ \\
\hline GVC: Linkage direction & $\begin{array}{c}\text { forward linkage|backward linkage|forward } \\
\text { link|backward link|buyer linkage|seller } \\
\text { linkage }\end{array}$ \\
\hline
\end{tabular}

Source: Own preparation.

\section{Review of the Factors}

The following is an overview of the twelve factors that have been identified in the course of the semisystematic literature review. The following sections show the main factors (categories of the literature review and qualitative text analysis), literature assigned to each factor, and the main findings of the literature review. There are several definitions of labor productivity in economic literature, but they are mostly similar (Table 3). Labor productivity is a measure of how effective is the employed labor, be it in an economy (aggregate labor productivity), region (regional labor productivity), or sector (sectoral labor productivity). 
Table 3. Definitions of labor productivity

\begin{tabular}{|c|c|}
\hline Source & Definition \\
\hline Cai et al. [3] & $\begin{array}{l}\text { Sectoral value added divided by labor force in } \\
\text { a sector }\end{array}$ \\
\hline $\begin{array}{l}\text { Constantinescu et } \\
\text { al. [4] }\end{array}$ & $\begin{array}{l}\text { "(...) real value- added divided by the number } \\
\text { of persons employed" }\end{array}$ \\
\hline $\begin{array}{l}\text { Dietzenbacher et } \\
\text { al. [5] }\end{array}$ & $\begin{array}{l}\text { "(...) we define labor productivity in vertically } \\
\text { integrated industry } i \text { as the ratio of value added } \\
\text { created in vertically integrated industry } i \text { and } \\
\text { the number of jobs in vertically integrated } \\
\text { industry } i \text { " }\end{array}$ \\
\hline Eurostat [6] & "(...) value added per employed person" \\
\hline Hatzikian [7] & $\begin{array}{l}\text { "(...) ratio between turnover or annual sales } \\
\text { and the number to employees in the reference } \\
\text { year }(\ldots) \text { "... }\end{array}$ \\
\hline Lemos [8] & "(...) output divided by number of employees" \\
\hline $\begin{array}{l}\text { McGowan et al. } \\
\text { [9] }\end{array}$ & “( $\ldots)$ gross output per employee $(\ldots) "$ \\
\hline $\begin{array}{l}\text { Mohnen \& Hall } \\
{[10]}\end{array}$ & “(...) amount of output per labor (...)" \\
\hline OECD [11] & "(...) output per unit of labour input" \\
\hline $\begin{array}{l}\text { Ortega-Argilés } \\
\text { [12] }\end{array}$ & “(...) GDP per hour worked (...)” \\
\hline
\end{tabular}

Source: Own preparation.

\subsection{Agglomerations Effect}

With rapidly increasing urbanization, the importance of cities in economic sciences is hard to overstate. Throughout numerous publications, agglomerations have been shown to have a significant positive impact on labor productivity. Notable examples include studies conducted in Sweden [13, 14], the Netherlands [15, 16], Italy [17], China [18, 19], and the United States [20, 21].

Agglomerations strongly influence labor productivity primarily because of the clustering of human capital (job density), increased R\&D expenditures, the effectiveness of investment, and multiple positive spillover effects. Agglomerations have a very strong positive impact on levels of labor productivity, mainly through the job density channel; at the same time, they negatively impact the future growth of labor productivity because of the harmful congestion effect [15]. Crucially, R\&D expenditure has a higher impact on labor productivity for firms located in agglomerations [14]. From the macroeconomic perspective, they almost universally increase the aggregate labor productivity of a country [15]. The positive spillovers have a surprisingly wide range, as the cities can have a positive influence on other cities located up to $100 \mathrm{~km}$ from each other [19]. Both urban areas and industrial districts have a positive impact on labor productivity, but the effect is stronger for urban areas as they increase the resilience to financial shocks [17]. In the context of urban planning, polycentric agglomerations have a higher positive impact on labor productivity than monocentric agglomerations [20].
There are, however, some significant caveats when assessing their impact on the economy. Firstly, agglomerations can also hurt the growth of labor productivity in some regions. There are productivity spillovers when surrounded by dense agglomerations, which increase aggregate productivity but hurt regional productivity; additionally, the density of neighboring regions can dampen the congestion channel [15]. Secondly, while they have a significant impact on regional labor productivity, they also actively increase economic inequality [18]. Finally, there are diminishing returns to labor productivity gain as agglomerations become too congested in time [16]. The dangers of the congestion spillovers and congestion in agglomeration themselves, as well as the tendency to have greater economic inequality in their populations, will only become exacerbated as a larger percentage of the population will move to the big cities.

\subsection{Business Cycles and Market Selection}

Business cycles periodically accelerate the process of market selection during an economic downturn. As such, their impact can be positive (due to Schumpeter's [22] creative destruction) or negative (due to lower output and accumulation). Recent studies have indeed confirmed the positive impact of crises on innovation [23-25]. Still, the global financial crisis and the following recession have had a negative impact on productivity in Europe [26].

The process of market selection has a more clear-cut impact on labor productivity. Market share reallocations resulting from market selection are important for labor productivity growth [27]. New entrants initially lower industry productivity growth, with time their contributions increase, and the biggest contributors to productivity growth are old and established firms experiencing productivity renewal [28]. Old firms with persistently low productivity (zombie firms) have a negative impact on aggregate industry productivity because they congest the market and waste invested capital [9]. According to a study conducted in Italy, manufacturing industries are characterized by the existence of several highly innovative firms and a larger number of regressive firms that exploit local markets, which can be described as neo-dualism of market selection [29].

Plant-level labor productivity is more vulnerable to business cycles than aggregate labor productivity of an economy [30]. Labor productivity moved in a countercyclical fashion during the Great Recession [31]. The procyclicality of labor productivity has declined greatly in the United States, at the same 
time there has been a rise in the relative volatility of employment and the real wages - a possible cause is a decline in the labor market turnover [32]. There is a high correlation between employment growth and business cycle vulnerability: long-run downsizers experience a much higher drop in productivity than long-run upsizers [30].

\subsection{Cross-country Institutional Differences}

Internationally, innovation is heavily localized and occurs mostly in countries with high capital intensity. Most productive firms are heavily clustered in rich and developed economies with a strong institutional framework. In 2008, the percentage of country's firms in the global top decile of firms with the highest productivity level was the largest in the following five countries: $35.5 \%$ in the United States, $27.3 \%$ in Sweden, $25.2 \%$ in Finland, $19.4 \%$ in France, and $16.5 \%$ in the Netherlands; other notable examples include $11 \%$ in Germany, $4.2 \%$ in Poland, and $3.5 \%$ in Japan [33]. Internationally, innovation is heavily localized and occurs mostly in countries with high capital intensity [34].

In advanced economies, a convergence in labor productivity has occurred, however, its level differs between industries; a probable cause of labor productivity convergence is the convergence in the capital-labor ratios [35]. In Western Europe, labor productivity convergence has occurred on the national and industry levels, especially in the manufacturing sector [5]. In OECD economies, relative prices and relative labor productivities are proportional in the long run [36]. In the 1990s, the relative demand for skilled labor increased in Poland and decreased in Hungary and Czechia, which was accompanied by growing wage inequality in all three countries [37].

There is a substantial difference in priorities (product innovation vs. process innovation) between European countries. Northern European countries (Germany, United Kingdom, and the Netherlands) focus primarily on product innovation and new technologies, while Southern European (France, Italy, and Portugal) countries focus primarily on process innovation and cost-minimization [38].

\subsection{Environmental Aspects}

In recent years, the environment, climate change, and the shift to green energy have become some of the most discussed topics in economic sciences. When it comes to labor productivity, the analyses focus on two primary issues: severe air pollution and a high-temperature working environment, which harm health-related labor productivity and product quality, especially in the long run. The most vulnerable sector is the construction industry. Given time, the average GDP is also highly likely to drop across the World.

Severe air pollution has a negative impact on labor productivity and product quality [39]. Prolonged exposure to air pollution has a small negative in the short run, however, long-term adverse effects might be more significant [40]. By 2060, air pollution will lower GDP by an average of $1 \%$, but this drop will be much more significant in China and Eastern Europe. Additionally, labor productivity will suffer because of the indirect impact of worsening health [41].

In the coming decades, climate change will most likely have a strong negative impact on labor productivity, especially in Southeast Asia and Central America [42]. Climate change-related labor productivity loss is most pronounced in regions where agriculture is dominant [43]. A hightemperature working environment hurts construction labor productivity $[44,45]$. The least productive and hazardous period of the day is between $2 \mathrm{pm}$ and 3 pm [44].

Trade openness, as well as offshoring of production by European countries to developing countries with labor-intensive production, where labor is cheaper but less efficient, hurt the environment globally. Green investment has a positive impact on labor productivity [46]. The impact of stringent environmental regulation on investment is a positive one, but with clear diminishing returns at the higher levels of environmental taxation [47]. Trade openness has a negative impact on emissions efficiency, $R \& D$ expenditure has no impact, and for manufacturing the impact varies across sectors [48]. Offshoring of production by European countries to developing countries with labor-intensive production harms the environment [49].

\subsection{Foreign Direct Investment (FDI)}

The impact of inward FDI on labor productivity is generally positive, however, it depends on certain factors like the development level of the receiving country (GDP per capita), types of linkages (positive for vertical and negative for horizontal), type of production (services vs. manufacturing), duration (positive for the long run), regional aspects, and industry strength. The initial impact of inward FDI on productivity is neutral, however, it shows a positive effect in the long run [50]. The impact of technology diffusion-related-FDI on productivity is positive for vertical linkages and negative for horizontal linkages [51]. The effect that FDI has on 
both host and home countries is undeniable, but its character depends greatly on the types of activities, level of competition, degree of internationalization, and host potential [52].

Several studies have focused on the effect on specific host countries. Inward FDI has no effect on domestic manufacturing labor productivity in the United States [53]. There has been a strong convergence effect on national and industry levels in Central and Eastern European countries with FDI playing a crucial role in this process [54]. FDI have a positive impact on productivity, but there is a big difference between inflows of FDI between regions in Romania: West is preferred to the East, and the capital region of Bucharest-Ilfov is much more heavily preferred than the rest of the country [55]. In China, FDI can have a positive impact on regional labor productivity and a negative impact on labor productivity in a given industry [56]. Higher per capita FDI inflow increases labor productivity in Chinese cities [57].

The impact of outward FDI on labor productivity is positive since it usually occurs in countries with prosperous and productive firms that extend or diversify their value chains. High FDI outflows are related to high productivity, on the other hand, high FDI inflows are related to an increase in productivity only for the countries above a certain GDP per capita threshold [58].

\subsection{Globalization and International Trade}

Firms that engage in international activities on average pay higher wages, conduct more innovative research, and have higher labor productivity. Exporting has a positive impact on productivity, and firms that export tend to pay higher wages and have higher R\&D expenditure $[59,60]$. Transnational corporations tend to have higher labor productivity and $R \& D$ expenditure than domestic firms [61, 62]. The size-wage effect shows that manufacturing labor productivity increases with firm size [63]. A firm's R\&D productivity has a positive relationship with the globalization of its enterprises and a negative relationship with industrial diversification [64]. Firms' high-growth status and their TFP growth have a strong positive correlation, with one reinforcing the other [65].

Trade liberalization has a positive impact on manufacturing labor productivity in developing countries $[66,67]$. The positive impact of financial liberalization on productivity is greater in the manufacturing sector than in the service sector [68]. Trade liberalization in services has a positive impact on the productivity of the manufacturing sectors when manufacturers benefit from using these services in the production process - this effect is especially noticeable in countries with a strong institutional environment [69]. Trade liberalization should be accompanied by reforms aimed at changes in ownership concentration; with regards to labor productivity in manufacturing, low ownership concentration is preferred with high tariffs, concentrated ownership is preferred with low tariffs [70].

A bilateral trade agreement between the United States and Vietnam has increased labor productivity in Vietnam by increasing employment in the more productive export-oriented formal sectors at the cost of a decrease in employment in the less productive informal sectors [71]. Manufacturing industries in Latin America have focused on raw material processing and labor-intensive production, where they held a natural comparative advantage; their rapid specialization resulted in unemployment and long-run external imbalances of the economies [72].

Cross-border acquisitions, outsourcing, and offshoring help manufacturing productivity, including low-skilled labor. Outsourcing and offshoring have a positive impact on manufacturing productivity $[73,74]$. International outsourcing has a positive impact on low-skilled labor productivity in the long run [75]. Cross-border acquisitions have a positive impact on domestic productivity, especially when the acquired firm is located in a more competitive market [76]. Additionally, high domestic competition increases the chances of cross-border acquisitions and the investment level of the domestic firm, in general, has a positive correlation with the increase in productivity resulting from cross-border acquisitions [76].

\subsection{Global value chains (GVC)}

Global value chains are one of the most important, and still relatively recent, additions to the literature on international economics. The crucial conclusion is that GVC participation has a significant positive impact on labor productivity [4, 77-79]. GVCs have a positive impact on labor productivity through four primary channels: firm specialization, easier access to inputs, knowledge spillovers, and increased competition [80]. Furthermore, GVCs tend to form as a consequence of regional clusters and activities of multinational enterprises [80].

Position in the chain is a key distinction for the estimation of the impact of GVCs. For upstream GVC activities, business cycle-related demand volatility has a negative impact on labor productivity [81]. A study of enterprises belonging to different GVC stages conducted in Italy and Spain shows a positive impact of agglomerations on 
labor productivity only for supplier firms [82]. When trade barriers exist, downstream GVC activities can be most cost-effectively placed in relatively central economies, as their proximity to locations of the upstream stages in the chain might outweigh the higher marginal cost; e.g. a country with lower labor productivity might still have a comparative advantage due to its location [83]. When it comes to domestic value-added, forward GVC linkages are more beneficial than backward GVC linkages [84]. In recent decades, production chains in China have lengthened, while those in the United States have shortened [85].

Another aspect is the type of labor utilized in a particular stage of the chain. According to Degain et al. [86], with regards to the rise of GVCs in the United States and other advanced economies, “(...) the big winners appear to be high-skilled workers and multinational corporations." GVCs are greatly beneficial to high-skilled workers with formal employment [87]. Rapid technological progress (Industry 4.0) has a chance to radically increase labor productivity and demand for high-skilled labor in GVCs [88]. However, in a study of GVCs in East Asia, Choi [89] finds that high-skilled labor productivity has not significantly contributed to value-added activities, as they were linked to limited technological innovation.

As usual, there are some important caveats. In recent years, GVCs' growth has slowed down [4, $80,86]$. As such, labor productivity growth has also slowed down, partly because of the sluggish GVC growth [4]. While GVCs have a positive impact on labor productivity, they have little impact on actual employment [79]. Ultimately, GVCs contribute to the transmission of international economic shocks [85].

GVCs are much more beneficial to advanced economies while developing countries' growth might even be hindered by them - still, for aggregate labor productivity alone their impact is generally positive regardless of the development level [90]. GVCs lead to an increase in labor productivity of advanced economies, however, this usually is accompanied by the outsourcing of the low-skilled labor to developing economies and increased unemployment in the former [86]. GVC integration has increased labor productivity in the Vietnamese garment and textile industries [91]. For developing countries, the need for higher labor productivity and the competitive pressure related to supplying a GVC might lead to an increase in informal employment with scarce work security [92]. Finally, Kummritz [78] finds that productivity gains are visible for both upstream/downstream activities as well as developed/developing countries.

\subsection{Human Capital}

Human capital has, unsurprisingly, a strong positive impact on labor productivity. Education (years of schooling and \% of tertiary education), health (nutrition, vaccines, and life expectancy), and technological progress are key elements of strong productivity growth.

Education and technological progress are the biggest contributors to labor productivity growth [93]. Human capital (high level of education) has a significant positive influence on labor productivity, however, for a low level of education, there is a significant negative relationship with labor productivity [94]. Depending on the situation, centralization or decentralization of education can have a positive impact on its quality and human capital. According to one study, to improve its human capital, China should decentralize higher education and centralize pre-tertiary rural education [95]. While education has no strong impact on agricultural productivity, it significantly increases off-farm income generation capabilities [96]. Effective human resource management, greater consideration for morale, and welfare all have a positive impact on labor productivity [97-99].

Knowledge spillovers help regional growth, which is most noticeable with close geographic proximity between urban areas. There are tertiary education spillovers with a highly positive impact on labor productivity [94]. The degree of impact of knowledge spillovers on regional productivity depends on geographic proximity, with neighboring regions benefiting the most from them [100]. An increase in human capital has a significant positive impact on regional labor productivity, however, this is negated by a significant negative impact of spatial spillovers [101]. From a perspective of a historically divided country, human capital is very similar between former West Germany and East Germany regions, but labor productivity is still noticeably higher in the West - potential explanations include historically larger firms and better infrastructure in the West [102].

Government expenditure can impact labor productivity. Government expenditures on education, agricultural research, and infrastructure have a positive impact on the economic growth of rural regions [103]. The use of vaccines has a positive impact on labor productivity [104]. In Mexico, violence and crime, and somewhat surprisingly anti-crime government expenditure, all negatively impact labor productivity [105]. Life 
expectancy and infrastructure have a significant positive impact on labor productivity in the agriculture sector [106]. Nutrition has a positive impact on agricultural labor productivity [107].

\subsection{Information and Communications Technology (ICT)}

The impact of information and communications technology on the entire economy is undeniably immense. Investment in ICT capital has a positive impact on labor productivity [108-111]. Investment in ICT capital has a bigger impact on labor productivity than non-ICT capital by $25 \%-50 \%$ [109]. ICT has been one of the primary causes of major productivity trend breaks (positive shocks) for the past decades. Major productivity trend breaks include years following wars (WWII), global financial crises (Great Depression, Great Recession), global supply shocks (oil shocks), idiosyncratic shocks (country level drastic policy changes), and technological breakthroughs (development of ICT in the USA) [112].

Internet access (as well as its quality and speed) have a positive impact on labor productivity. Digitalization and access to information made possible by the Internet are important for inclusivity. Internet access and data standardization have a positive impact on labor productivity [110]. The impact of broadband access on labor productivity is positive, but its strength relies on better connection quality and is more pronounced for less developed regions - which makes it a tool for regional convergence [113].

In the late 1990s and early 2000s, total labor productivity in Germany, which at the time was one of the global leaders, has suffered because of limited gains in the ICT-intensive sectors despite large investments [114]. However, for ITC-intensive manufacturers since the 1990s in the United States, labor productivity growth is influenced mostly by the decline in output $(\mathrm{Y})$ and decline in employment (L), and not in real improvements [115].

\subsection{Labor Allocation}

Labor allocation includes primarily the processes of labor mobility and migration. Skilled labor mobility has a positive impact on the manufacturing productivity of the receiving industry, especially in the case of employment in the high-tech sectors $[116,117]$. Worker reallocation from less to more innovative firms has a positive impact on aggregate labor productivity [118]. Migration has a positive impact on income convergence rate; immigration into regions with high income per capita pushes the value down, while emigration from low-income regions pushes per capita values up [119].

Labor unions have a positive impact on manufacturing labor productivity [120]. The use of temporary contracts has a small negative impact on labor productivity [121]. External labor flexibility has a negative impact on productivity growth in Italy, which is especially noticeable in SMEs [122]. Labor market distortions lower labor productivity and the speed of convergence between regions in China, which is especially exemplified by artificial labor mobility barriers and inferior social security systems in rural areas [3].

Vergeer and Kleinknecht [123] show that higher wages lead to an increase in labor productivity, while high labor turnover decreases productivity. Consequently, a higher wage share of labor has a positive impact on labor productivity, while income inequality has a negative one [124]. Wage share in advanced economies has decreased in the past decades [125].

In the United States, plants that have increased labor productivity done so either by downsizing or by increasing their output with upsized employment - manufacturers in mature industries tended to downsize (i.e. steel industry), while there have been some correlation of upsizing to a regional location (i.e. New England) and firm size (i.e. large firms) [126]. Also in the United States, Snowbelt states have experienced a higher level of manufacturing labor productivity growth than Sunbelt states, at the same time they lost employment while sunbelt states gained employment [127].

\subsection{R\&D and Innovation}

Research and development expenditure and intensity have a very strong positive impact on labor productivity for both manufacturing and services. R\&D expenditure has a clear-cut positive impact on labor productivity $[10,128-135]$. $R \& D$ is positively correlated with firm size, $R \& D$ intensity is negatively correlated with firm size, and $R \& D$ intensity is positively correlated with future innovations [129]. The impact of $R \& D$ on labor productivity is positive for both manufacturing and services. Regional specialization is more important for labor productivity in services than in manufacturing [134]. Creative service industry specializations have a positive impact on regional labor productivity [136]. R\&D intensity has a positive impact on labor productivity; this effect is especially noticeable in advanced industries [133]. Lack of availability of qualified personnel and the availability of finance harm firms' productivity 
[137]. In general, R\&D expenditure has a positive influence on the innovativeness of MSMEs [129].

Intangible investments have a positive impact on labor productivity [138-140]. The positive impact of intangible investment on labor productivity is the highest in the manufacturing and finance industries [139]. Technology acquisition expenditures have a positive impact on productivity [130].

The impact of product innovation on productivity is positive, but the impact of process innovation is less unequivocal [141]. The impact of innovation intensity on labor productivity follows a U-curve [7]. The crucial element of inducing productivity growth in the early stages of economic development is the widespread use of technology [142]. In Latin America, two determinants of innovation crucial for the region have been observed: public support and the intellectual property rights system [131]. Technology shocks have a positive impact on labor productivity [143] Sudden losses in human capital have a much stronger short-run and long-run impact on innovation than physical capital [144].

\subsection{Regional Differences}

Regional differences can be difficult to measure, as the quantitative analysis of institutions and other factors is more difficult than in the international comparisons. Consequently, further exploration of regional differences and convergence/divergence trends could be an important topic of future research.

In the 1980s, there has been a significant regional labor productivity convergence across Europe [145]. The polarization was present in the regional labor productivity of the European Union. At the sectoral level, regional labor productivity polarization was present in the services, but not in manufacturing [146]. This can be explained by the concentration of highly productive tradable services in agglomerations and interregional differences in productivity in non-tradable services. Productivity of non-tradable services results to a greater extent from the level of wages in a given region, as the demand for them is local and they can be provided locally. While tradable services can be provided remotely, which is often done, for example, in service centers located in agglomerations. There are two equilibria in regional productivity growth, with high-productivity regions converging in the center of Europe, and low-productivity regions converging in the peripheries. The low-productivity convergence is a type of low-productivity trap [147]. Since the early 1980 s, regional convergence in labor productivity in Spain had stopped as there has been limited technological diffusion between the regions; convergence occurs in aggregate labor productivity at the regional level but not at the sectoral level [148, 149]. Regional labor productivity in Russia has converged [150].

Productivity levels across regions in the United States are highly differentiated. The main forces in labor productivity convergence have been the manufacturing and mining sectors [151]. Differences in productivity across regions were caused by different growth rates of capital and labor input [152].

In the past, the labor productivity and agricultural surplus in China were high and unevenly spread between regions. Labor productivity in agriculture was much lower than in manufacturing; increased urbanization improves labor productivity in rural areas [153]. China's East Rim provinces have had higher labor productivity and labor productivity growth than the rest of the country [154]. Increases in regional labor productivity in China were mostly the results of new labor-saving processes [155]. In 1995, the labor surplus in agriculture in China was substantial (120 million), with very large differences between regions: $44.8 \%$ of the agriculture labor force for the Southwest region and $0.3 \%$ for the Northeast region [153].

\section{Qualitative Text Analysis}

The qualitative text analysis section of this article presents the results of the computer-assisted qualitative data analysis using Atlas.ti software. There are 141 publications used in the qualitative text analysis. A small but notable number of works cited in this article play a supporting role (e.g. provide methodological context), as such, they are not included in the qualitative analysis $[1,2,8,12$, $22-25,52,123-125]$. This analysis is based on the concepts of codes and sub-codes: they are assigned quotes (portions of the reviewed literature). If their quotes overlap it means that the codes (or subcodes) co-occur with other codes (or sub-codes). The co-occurrence is measured using the cooccurrence count (the number of times they cooccur) and the c-coefficient (the number of times they co-occur adjusted for the size of each code). The former is an integer, and the latter is a standardized coefficient (between 0 and 1). If the codes co-occur, we can assume that there is some interdependence between them. 


\subsection{Bibliometric Analysis}

The bibliometric analysis is using the Web of Science analyzing tool. Fig. 1 shows the number of articles per year for the search term "labo*r productivity" (considering both spellings) available in the Web of Science Core Collection (WoS-CC) and Web of Science all databases (WoS-AD). Even though labor productivity is a very old concept, the trend clearly shows a rapidly growing interest, indicating its timelessness. As of today, and the number is sure to increase as the database gets updated, there have been 1,013 publications in the WoS-AD and 572 publications in the WoS-CC in 2019 alone. For the entire analyzed period, there are 8,962 publications in the WoS-AD and 5,373 in the WoS-CC. The numbers emphasize how vast this topic is, and that the semi-systematic approach is advantageous.

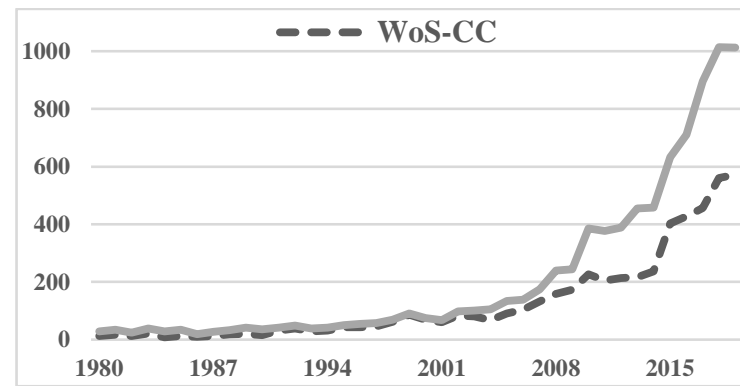

Fig. 1: Bibliometric trends of labor productivity, 1980-2019

Source: Own preparation based on the Web of Science [156].

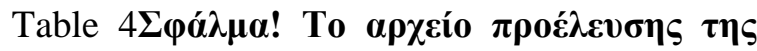

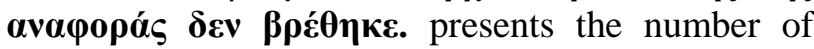
publications on selected search topics in the WoSCC for the 1980-2019 period. The percentage increase is the number of publications compared to the preceding decade. Notable figures include the increase in ICT-related publications, especially in 2000-2009 (1,229\%), the explosion of popularity of globalization since the 1990s, and the consistent popularity of R\&D. For GVC, 2019 alone brought 106 publications (15\% of total). Of course, it is hard to directly compare these topics, as some of them are much broader, but it should give a general idea of how crucial they are to any economic analysis in particular that of labor productivity.
Table 4. Number of publications on selected search topics, WoS-CC, 1980-2019

\begin{tabular}{|c|c|c|c|c|c|c|c|}
\hline \multirow{2}{*}{ Search topic } & \multirow{2}{*}{$\begin{array}{l}1980- \\
1989 \\
\end{array}$} & \multirow{2}{*}{$\begin{array}{l}1990- \\
1999\end{array}$} & \multicolumn{2}{|c|}{$2000-2009$} & \multicolumn{2}{|c|}{$2010-2019$} & \multirow[b]{2}{*}{ Total } \\
\hline & & & number & $\%$ increase & number & $\%$ increase & \\
\hline "labo"r productivity" & 144 & 427 & 1,021 & 139 & 3,519 & 245 & 5,111 \\
\hline "agglomerations" & 18 & 216 & 605 & 180 & 2,495 & 312 & 3,334 \\
\hline "business cycle" & 225 & 1,128 & 2,388 & 112 & 5,371 & 125 & 9,112 \\
\hline "market selection" & 7 & 20 & 116 & 480 & 271 & 134 & 414 \\
\hline $\begin{array}{l}\text { "international } \\
\text { differences" }\end{array}$ & 44 & 147 & 251 & 71 & 472 & 88 & 914 \\
\hline "environmental aspects" & 120 & 606 & 1,097 & 81 & 3,425 & 212 & 5,248 \\
\hline "FDI" & 27 & 621 & 3,075 & 395 & 8,940 & 191 & 12,663 \\
\hline "human capital" & 222 & 1,601 & 4,786 & 199 & 15,026 & 214 & 21,635 \\
\hline "GVC" & 94 & 113 & 81 & -28 & 420 & 419 & 708 \\
\hline "ICT" & 37 & 503 & 6,684 & 1,229 & 32,129 & 381 & 39,353 \\
\hline "international trade" & 695 & 2,085 & 4,236 & 103 & 12,224 & 189 & 19,240 \\
\hline "globali*ation" & 58 & 3,452 & 19,638 & 469 & 45,210 & 130 & 68,358 \\
\hline "labo*r mobility" & 48 & 156 & 353 & 126 & 987 & 180 & 1,544 \\
\hline "labo"r allocation" & 5 & 40 & 77 & 93 & 135 & 75 & 257 \\
\hline "regional convergence" & 1 & 41 & 161 & 293 & 321 & 99 & 524 \\
\hline "R\&D" & 123 & 8,696 & 19,258 & 121 & 30,317 & 57 & 58,394 \\
\hline
\end{tabular}

Source: Own preparation based on the Web of Science database (Accessed 17.07.2020).

\subsection{Codes}

Fig. 2 and Table 5 show the word count for the reviewed literature $(n=141)$. For clarity, we omit the common words irrelevant to the topic like "the," "we," "and," etc. This figure and table are the only ones that differentiate between different spellings (e.g. labor/labour). As expected, "productivity" is by far the most common word, followed by "labor" (American spelling), "growth," "capital," and "data." The word count list is interesting in its own right, but its primary function is to help with the initial exploration of literature and the creation of codes (factors) and sub-codes.

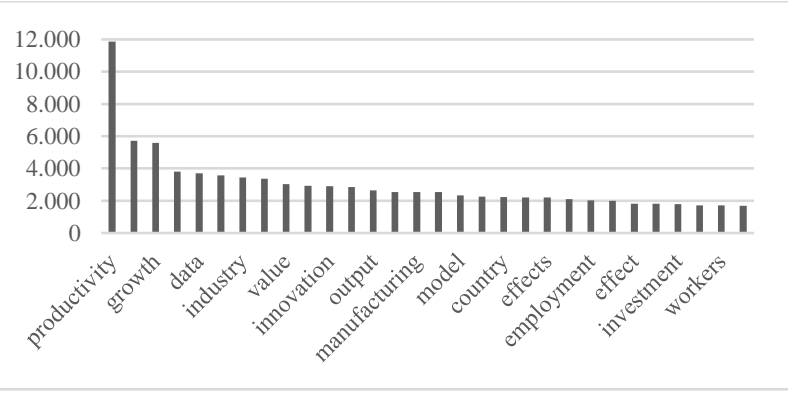

Fig. 2: Word count

Source: Own preparation.

Table 5. Word count

\begin{tabular}{|c|c|c|c|c|c|}
\hline productivity & 11,871 & share & 1,626 & global & 1,095 \\
\hline labor & 5,724 & regions & 1,614 & estimates & 1,091 \\
\hline growth & 5,583 & regional & 1,603 & business & 1,090 \\
\hline capital & 3,810 & market & 1,579 & OECD & 1,083 \\
\hline data & 3,698 & across & 1,534 & FDI & 1,060 \\
\hline level & 3,564 & labour & 1,529 & empirical & 1,006 \\
\hline industry & 3,450 & sectors & 1,503 & worker & 1,005 \\
\hline countries & 3,363 & foreign & 1,429 & knowledge & 983 \\
\hline value & 3,031 & variable & 1,426 & relative & 976 \\
\hline economic & 2,937 & research & 1,388 & region & 969 \\
\hline innovation & 2,913 & rate & 1,375 & increase & 968 \\
\hline production & 2,858 & impact & 1,365 & product & 967 \\
\hline output & 2,638 & size & 1,303 & input & 961 \\
\hline results & 2,543 & international & 1,302 & process & 955 \\
\hline manufacturing & 2,541 & economics & 1,289 & European & 944 \\
\hline trade & 2,534 & domestic & 1,287 & measures & 942 \\
\hline model & 2,323 & technology & 1,266 & aggregate & 935 \\
\hline industries & 2,260 & convergence & 1,263 & world & 934 \\
\hline
\end{tabular}




\begin{tabular}{|c|c|c|c|c|c|} 
country & 2,235 & work & 1,259 & China & 932 \\
\hline firms & 2,211 & they & 1,253 & economies & 930 \\
\hline effects & 2,193 & percent & 1,188 & performance & 924 \\
\hline sector & 2,105 & income & 1,165 & costs & 919 \\
\hline employment & 2,033 & development & 1,161 & inputs & 914 \\
\hline average & 2,010 & activities & 1,124 & spatial & 914 \\
\hline effect & 1,822 & products & 1,120 & factor & 859 \\
\hline variables & 1,806 & firm & 1,119 & information & 859 \\
\hline investment & 1,795 & levels & 1,116 & EU & 845 \\
\hline services & 1,716 & TFP & 1,114 & GVC & 843 \\
\hline workers & 1,702 & human & 1,111 & industrial & 839 \\
\hline analysis & 1,676 & ICT & 1,104 & national & 836 \\
\hline
\end{tabular}

Source: Own preparation.

Table 6 shows the number of quotes per code $(n=12)$ and sub-code $(n=49)$ for the reviewed literature $(n=141)$. The number in the brackets is the number of papers with at least one quote for this code (the maximum possible value would be 141). The assigned codes are: (i) agglomerations effect; (ii) business cycles and market selection; (iii) crosscountry institutional differences; (iv) environmental aspects; (v) foreign direct investment (FDI); (vi) globalization and international trade; (vii) global value chains (GVC); (viii) human capital; (ix) information and communications technology (ICT); (x) labor allocation; (xi) R\&D and innovation; (xii) regional differences.

The number of quotes per code is different than the sum of its sub-codes since the codes also include generic terms (e.g. R\&D). The more general subcodes (e.g. innovation) have a higher number of quotes than the more specialized sub-codes (e.g. product innovation). There are is one dominant factor with more than three thousand quotes: (xi) R\&D. Other prominent codes are (vi) globalization and (viii) human capital, with more than two thousand quotes. The code with the lowest quote count is (iii) country differences. (i) Agglomerations are especially interesting, as most of its quotes cooccur with other codes.

While the publications are assigned to a single code in the review, the qualitative analysis shows that these topics are difficult to isolate. Most of the codes occur at least once in the majority of the analyzed literature, e.g. the code for human capital occurs in 133 publications. When it comes to quotes per individual publications, the average is 218 and the median is 181 . There are seven publications with more than 500 quotes: Antràs \& Gortari [83], Crespi \& Zuniga [131], Criscuolo \& Timmis [80], Degain et al. [86], Foster-McGregor \& Pöschl [116], FuchsSchündeln \& Izem [102], and Kummritz et al. [84].

Table 6. Number of quotes per code and sub-code

\begin{tabular}{|l|r|l|r|l|r|}
\hline $\begin{array}{l}\text { (i) } \begin{array}{l}\mathbf{2 , 6 7} \\
\text { IONS }\end{array} \\
\text { Congestion }\end{array}$ & $\begin{array}{r}\mathbf{1 , 7 5} \\
\mathbf{1}\end{array}$ & $\begin{array}{l}\text { (vi) } \\
\text { GLOBALIZA }\end{array}$ & $\begin{array}{r}\mathbf{6} \\
\text { TION }\end{array}$ & $\begin{array}{r}\text { Internet } \\
\mathbf{5}]\end{array}$ & 250 \\
\hline 115 & $\begin{array}{l}\text { Financial } \\
\text { liberalization }\end{array}$ & 20 & $\begin{array}{l}\text { (x) LABOR } \\
\text { ALLOCATI } \\
\text { ON }\end{array}$ & $\begin{array}{r}\mathbf{6 1 5} \\
{[72]}\end{array}$ \\
\hline
\end{tabular}

\begin{tabular}{|c|c|c|c|c|c|}
\hline $\begin{array}{l}\text { Employment } \\
\text { density }\end{array}$ & 60 & Outsourcing & 376 & $\begin{array}{l}\text { Employment } \\
\text { type }\end{array}$ & 51 \\
\hline Spillovers & 666 & Trade & $\begin{array}{r}2,04 \\
2\end{array}$ & Labor market & 265 \\
\hline $\begin{array}{l}\text { (ii) BUSINESS } \\
\text { CYCLES }\end{array}$ & $\begin{array}{r}823 \\
{[11} \\
5]\end{array}$ & $\begin{array}{l}\text { Trade } \\
\text { liberalization }\end{array}$ & 137 & $\begin{array}{l}\text { Labor } \\
\text { mobility }\end{array}$ & 94 \\
\hline Crisis & 261 & $\begin{array}{l}\text { Transnational } \\
\text { corporations }\end{array}$ & 148 & Migration & 191 \\
\hline $\begin{array}{l}\text { Employment } \\
\text { (total) }\end{array}$ & 559 & (vii) GVC & $\begin{array}{r}1,06 \\
7 \\
{[24]} \\
\end{array}$ & $\begin{array}{l}\text { Worker } \\
\text { reallocation }\end{array}$ & 47 \\
\hline Market selection & 46 & $\begin{array}{l}\text { Downstream } \\
\text { activities }\end{array}$ & 59 & (xi) $R \& D$ & $\begin{array}{r}3,11 \\
7 \\
{[108}\end{array}$ \\
\hline Procyclicality & 74 & $\begin{array}{l}\text { Linkage } \\
\text { direction }\end{array}$ & 56 & Innovation & $\begin{array}{r}2,09 \\
1\end{array}$ \\
\hline $\begin{array}{l}\text { (iii) COUNTRY } \\
\text { DIFFERENCES }\end{array}$ & $\begin{array}{l}479 \\
{[97]}\end{array}$ & $\begin{array}{l}\text { Upstream } \\
\text { activities }\end{array}$ & 84 & $\begin{array}{l}\text { Intangible } \\
\text { investment }\end{array}$ & 287 \\
\hline $\begin{array}{l}\text { Country } \\
\text { specialization }\end{array}$ & 75 & $\begin{array}{l}\text { Vertical } \\
\text { integration }\end{array}$ & 53 & $\begin{array}{l}\text { Process } \\
\text { innovation }\end{array}$ & 105 \\
\hline Institutions & 350 & $\begin{array}{l}\text { (viii) HUMAN } \\
\text { CAPITAL }\end{array}$ & $\begin{array}{r}2,41 \\
7 \\
{[13} \\
3]\end{array}$ & $\begin{array}{l}\text { Product } \\
\text { innovation }\end{array}$ & 92 \\
\hline Relative prices & 42 & Education & 678 & $\begin{array}{l}\text { R\&D } \\
\text { expenditure }\end{array}$ & 40 \\
\hline $\begin{array}{l}\text { (iv) } \\
\text { ENVIRONMEN } \\
T\end{array}$ & $\begin{array}{r}813 \\
{[76]}\end{array}$ & Health & 480 & $\begin{array}{l}\text { R\&D } \\
\text { intensity }\end{array}$ & 81 \\
\hline Air pollution & 117 & Healthcare & 38 & $\begin{array}{l}\text { (xii) } \\
\text { REGIONAL } \\
\text { DIFFEREN } \\
\text { CES }\end{array}$ & $\begin{array}{r}1,41 \\
6 \\
{[102} \\
]\end{array}$ \\
\hline Climate change & 70 & Knowledge & 889 & $\begin{array}{l}\text { Beta } \\
\text { convergence }\end{array}$ & 14 \\
\hline Green investment & 63 & Life expectancy & 19 & Convergence & 808 \\
\hline (v) FDI & $\begin{array}{r}827 \\
{[51]}\end{array}$ & (ix) ICT & $\begin{array}{r}1,06 \\
2 \\
{[66]}\end{array}$ & $\begin{array}{l}\text { Geographic } \\
\text { location }\end{array}$ & $\begin{array}{r}1,12 \\
8\end{array}$ \\
\hline Investment policy & 12 & ICT capital & 247 & $\begin{array}{l}\text { Sigma } \\
\text { convergence }\end{array}$ & 32 \\
\hline Inward FDI & 79 & $\begin{array}{l}\text { ICT intensive } \\
\text { industry }\end{array}$ & 43 & \multirow[t]{2}{*}{ TOTALS: } & \multirow{2}{*}{$\begin{array}{r}30,6 \\
75\end{array}$} \\
\hline Outward FDI & 8 & ICT investment & 70 & & \\
\hline
\end{tabular}

\section{Source: Own preparation.}

Fig. 3 shows a simple network view of the codes and sub-codes. Fig. 4 shows a network view with weighted edges (using the number of quotes as weights). Fig. 5 shows the connections between the 12 codes (factors of labor productivity) and 141 publications; the exact number of edges per code/node is provided in Table 6 . The factors and literature are highly interconnected and virtually impossible to analyze in a vacuum. The next section of this article deals with co-occurrence measures for the reviewed literature. 


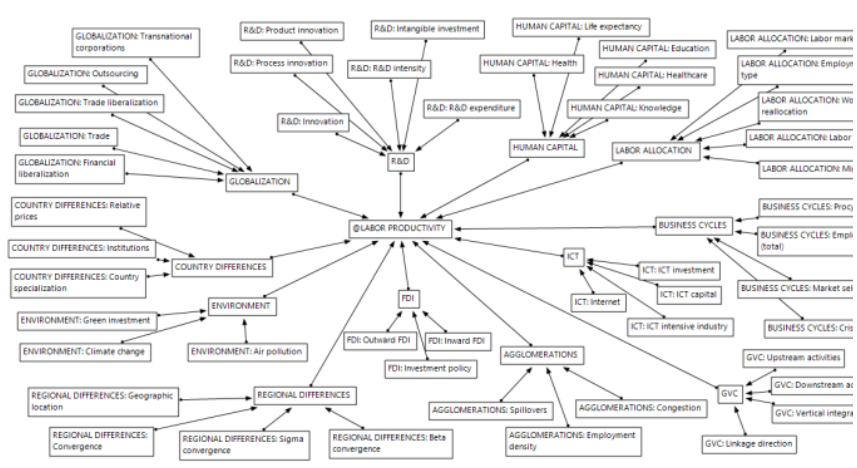

Fig. 3: Network view: overview

Source: Own preparation.

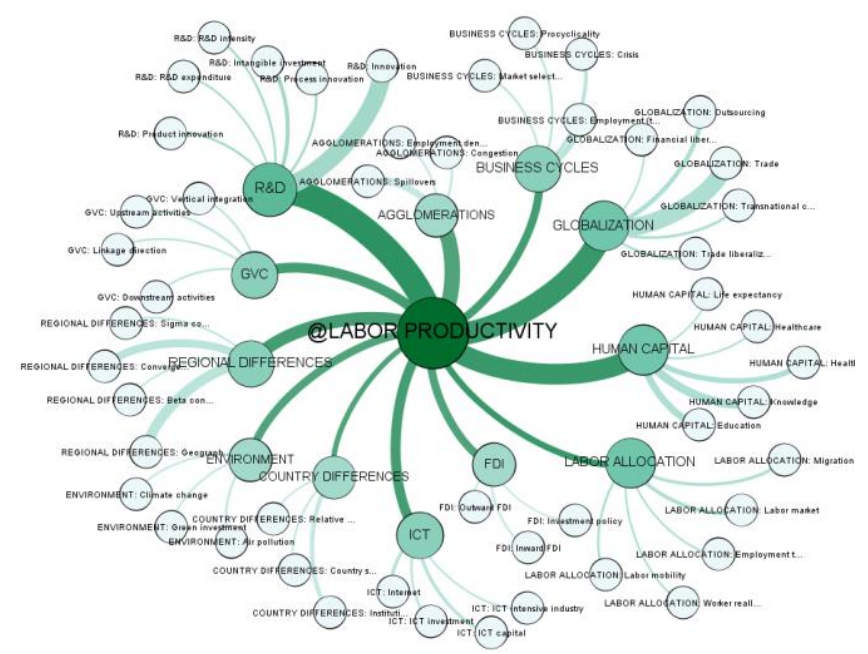

Fig. 4: Network view: weighted edges

Source: Own preparation.

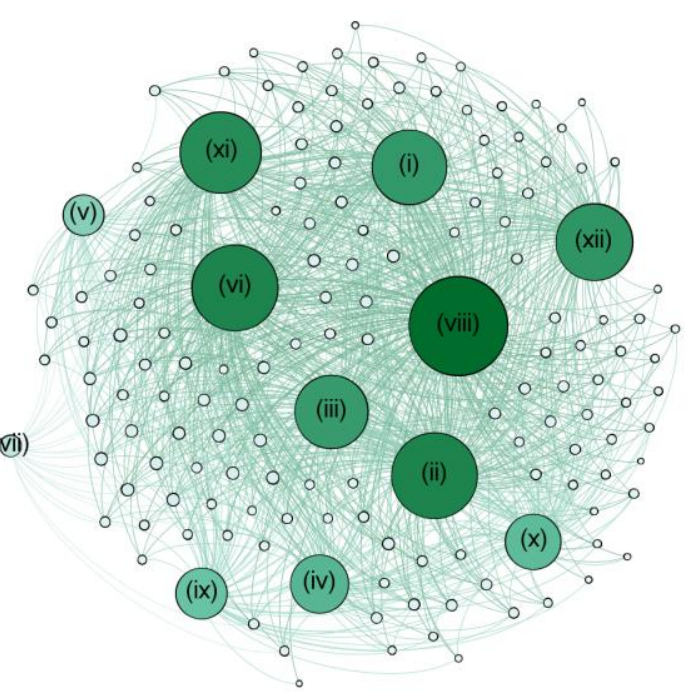

Fig. 5: Network view: codes and publications Source: Own preparation.

\subsection{Co-occurrence}

While the number of quotes is determined by the choice of publications, the co-occurrence analysis should provide a more nuanced result.
Table 7 presents the co-occurrence between codes and the c-coefficient $(n=12)$ for the reviewed literature $(n=141)$. The upper-right portion of the table shows the co-occurrence count, while the bottom-left portion shows the c-coefficient. The use of the c-coefficient allows for a fairer comparison of co-occurrence since it takes into consideration how numerous the code count is for each code.

The following two codes have the highest cooccurrence count and c-coefficient: (viii) human capital and (i) agglomerations. The code with the third-highest co-occurrence count is (xi) $\mathrm{R} \& \mathrm{D}$, and the code with the third-highest c-coefficient is (vi) globalization. Among which, (viii) human capital leads the overall total co-occurrence count with 1,231 and the c-coefficient with 0.32 - the latter is tied with the result of (i) agglomerations. In general, the four leading codes (human capital, agglomerations, $\mathrm{R} \& \mathrm{D}$, globalization) are the most important in this analysis and the differences in their scores are relatively small.

There is a notable cluster of scientific interest between $\mathrm{R} \& \mathrm{D} / \mathrm{human}$ capital/agglomerations, visible in the crucial code dyads of (viii) human capital and (i) agglomerations, as well as (viii) human capital and (xi) R\&D. There is also a high co-occurrence dyad of (i) agglomerations and (v) FDI. Another one is between (vi) globalization and (vii) GVC. This shows how the literature on international trade, the role of large multinational corporations, and knowledge spillovers play a crucial part in explaining labor productivity and its growth. These results are rather intuitive, as agglomerations have been shown to concentrate and enhance the regional human capital in densely populated, small areas, which in turn attracts investments. Globalization and global value chains are similarly interconnected. Noteworthy code dyads (with c-coefficient of 0.04 or higher) include:

- (i) agglomerations and (viii) human capital (294, 0.08);

- (i) agglomerations and (v) FDI (163, 0.07);

- (viii) human capital and (xi) R\&D (301, 0.06);

- (vi) globalization and (vii) GVC (190, 0.05);

- (i) agglomerations and (x) labor allocation $(85,0.04)$.

On the other hand, and somewhat surprisingly, the total co-occurrence count and c-coefficient for (ix) ICT are the lowest $(224,0.08)$. ICT is ubiquitous and has a profound effect on almost every aspect of modern business life, yet the literature on its impact on labor productivity is somewhat confined to a relatively modest number of papers. A possible explanation could be that the impact is so great, that general economic models are 
taking it for a given (exogenous variable) - or perhaps there are issues with quantifying it. Other codes with relatively low total co-occurrence count are (x) labor allocation (350), (iii) country differences (387), and the (iv) environment (392). For the latter, most of its co-occurrences (88) are related to (viii) human capital, which makes sense as the environmental damage is sure to cause health problems, which in turn lowers labor productivity. The environmental aspects are relatively new to economic analysis - at least compared to other factors presented in this review. Their analysis is sometimes pushed outside of the mainstream macroeconomic and microeconomic models, be it for methodological difficulties or ideological differences.

Table 7. Co-occurrence count between codes and the c-coefficient

\begin{tabular}{|c|c|c|c|c|c|c|c|c|c|c|c|c|c|}
\hline CODE & (i) & (ii) & (iii) & (iv) & (v) & (vi) & (vii) & (viii) & (ix) & (x) & (xi) & (xii) & TOTALS \\
\hline (i) & - & 48 & 32 & 32 & 163 & 89 & 41 & 294 & 23 & 85 & 149 & 70 & $\mathbf{1 , 0 2 6}$ \\
\hline (ii) & 0.02 & - & 13 & 10 & 17 & 72 & 22 & 86 & 18 & 36 & 61 & 31 & $\mathbf{4 1 4}$ \\
\hline (iii) & 0.01 & 0.01 & - & 39 & 21 & 92 & 34 & 53 & 9 & 16 & 58 & 20 & $\mathbf{3 8 7}$ \\
\hline (iv) & 0.01 & 0.01 & 0.03 & - & 26 & 77 & 10 & 88 & 4 & 6 & 90 & 10 & $\mathbf{3 9 2}$ \\
\hline (v) & 0.07 & 0.01 & 0.02 & 0.02 & - & 95 & 28 & 66 & 6 & 10 & 50 & 33 & $\mathbf{5 1 5}$ \\
\hline (vi) & 0.02 & 0.02 & 0.03 & 0.02 & 0.03 & - & 190 & 107 & 25 & 32 & 153 & 61 & $\mathbf{9 9 3}$ \\
\hline (vii) & 0.01 & 0.01 & 0.02 & 0.01 & 0.02 & 0.05 & - & 31 & 18 & 7 & 23 & 1 & $\mathbf{4 0 5}$ \\
\hline (viii) & 0.08 & 0.03 & 0.02 & 0.03 & 0.02 & 0.02 & 0.01 & - & 50 & 79 & 301 & 76 & $\mathbf{1 , 2 3 1}$ \\
\hline (ix) & 0.01 & 0.01 & 0.01 & 0 & 0 & 0.01 & 0.01 & 0.01 & - & 4 & 55 & 12 & $\mathbf{2 2 4}$ \\
\hline (x) & 0.04 & 0.03 & 0.01 & 0 & 0.01 & 0.01 & 0 & 0.03 & 0 & - & 18 & 57 & $\mathbf{3 5 0}$ \\
\hline (xi) & 0.03 & 0.02 & 0.02 & 0.02 & 0.01 & 0.03 & 0.01 & 0.06 & 0.01 & 0 & - & 48 & $\mathbf{1 , 0 0 6}$ \\
\hline (xii) & 0.02 & 0.01 & 0.01 & 0 & 0.01 & 0.02 & 0 & 0.02 & 0 & 0.03 & 0.01 & - & $\mathbf{4 1 9}$ \\
\hline TOTALS & $\mathbf{0 . 3 2}$ & $\mathbf{0 . 1 7}$ & $\mathbf{0 . 1 9}$ & $\mathbf{0 . 1 6}$ & $\mathbf{0 . 2 1}$ & $\mathbf{0 . 2 6}$ & $\mathbf{0 . 1 5}$ & $\mathbf{0 . 3 2}$ & $\mathbf{0 . 0 8}$ & $\mathbf{0 . 1 7}$ & $\mathbf{0 . 2 2}$ & $\mathbf{0 . 1 5}$ & - \\
\hline
\end{tabular}

Source: Own preparation.

Fig. 6 presents the network view of the co-occurrence count, while

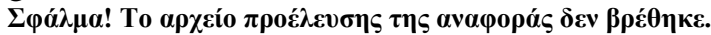
visualizes one for the c-coefficient. The exact numbers for both figures are given in

Table 7. Both graphs have size-scaled nodes (by weighted degree) and edges (by weight value). We use modularity analysis to reveal two communities. The first community is centered around (i) agglomerations and (viii) human capital. The second one is centered around (vi) globalization. The node for (xi) $R \& D$ is visibly smaller when analyzing the c-coefficient. If codes are in the same community (modularity class) it means they are more likely to co-occur with other codes in the same community (modularity class). The figures show that whether we use the co-occurrence count or the c-coefficient the results are very similar, and only one code (ix) changes its community.

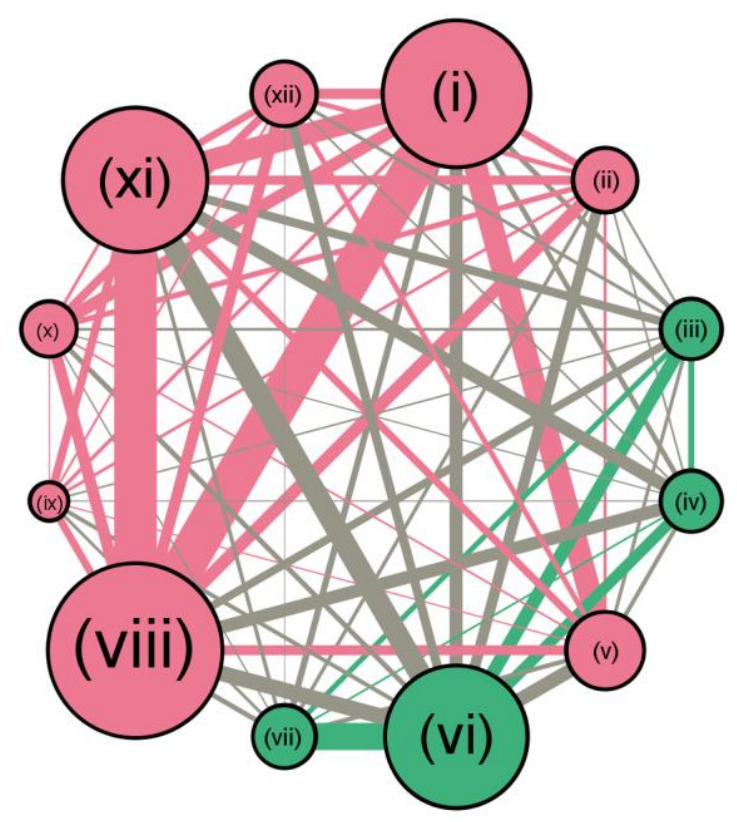

Fig. 6: Network view: co-occurrence count Source: Own preparation. 


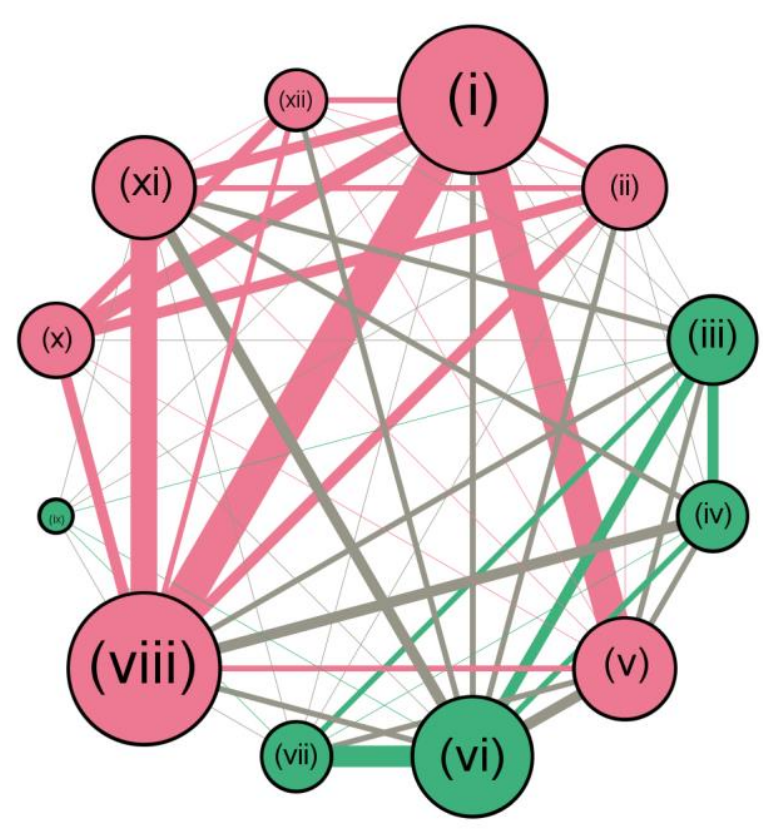

Fig. 7: Network view: c-coefficient Source: Own preparation.

Finally, we focus on the interdependencies between the sub-codes.

visualizes the co-occurrence between all subcodes. The colors are determined by modularity class (codes in the same community that are more likely to co-occur with each other). This time there are seven modularity classes (communities). Table 8 shows the co-occurrence between 39 selected subcode dyads for the reviewed literature $(n=141)$. The pairs were selected in the following way:

- the 3 pairs with the highest co-occurrence count per category (factor) are chosen;

- due to some degree of overlap, both sub-codes in the pair cannot be from the same category;

- when both categories share each other's highest pair, the pair is repeated but in reverse order;

- if there is an equal number of co-occurrences, all pairs are included and the category has more than 3 pairs.

As per above, every dyad in the table is notable because of its placement in the top three according to the co-occurrence count for its factor (code). Many of them are seemingly obvious, like spillovers/knowledge or innovation/knowledge. Some, however, should and have been of particular interest to economic research. The close relation between institutions, trade, and innovation signifies the ever-growing importance of a strong institutional framework for modern economies. While globalization is fraught with dangers, from a strictly theoretical standpoint, its benefits are almost overwhelming when implemented correctly. For business cycles, the main questions are how geography, trade, and education determine differences in total employment between regions. Another important cluster of interest is formed by the relations between labor mobility and knowledge spillovers as well as between migration and regional convergence. Migration, both interregional and international, has become of the most hot-button issues in political discourse, so economic analyses must present its impact as clear as possible. Finally, the link between the environmental aspects (air pollution and climate change) and their impact on the decline in labor productivity due to worsening health has to become one of the paramount issues in economics.

Table 8 Co-occurrence between selected sub-codes

\begin{tabular}{|c|c|c|}
\hline Sub-code 1 & Sub-code 2 & $\begin{array}{c}\text { Coun } \\
t\end{array}$ \\
\hline Spillovers & Knowledge & 166 \\
\hline Spillovers & Innovation & 63 \\
\hline Spillovers & Trade & 37 \\
\hline $\begin{array}{l}\text { Employment } \\
\text { (total) }\end{array}$ & $\begin{array}{c}\text { Geographic } \\
\text { location }\end{array}$ & 45 \\
\hline $\begin{array}{l}\text { Employment } \\
\text { (total) }\end{array}$ & Education & 45 \\
\hline $\begin{array}{l}\text { Employment } \\
\text { (total) }\end{array}$ & Trade & 30 \\
\hline Institutions & Trade & 54 \\
\hline Institutions & Innovation & 35 \\
\hline $\begin{array}{c}\text { Country } \\
\text { specialization }\end{array}$ & Trade & 20 \\
\hline Air pollution & Health & 24 \\
\hline Climate change & Health & 15 \\
\hline Green investment & Innovation & 11 \\
\hline Inward FDI & Spillovers & 8 \\
\hline Inward FDI & Convergence & 7 \\
\hline Inward FDI & $\begin{array}{c}\text { Geographic } \\
\text { location }\end{array}$ & 7 \\
\hline Trade & $\begin{array}{l}\text { Geographic } \\
\text { location }\end{array}$ & 70 \\
\hline Trade & Innovation & 60 \\
\hline Trade & Institutions & 54 \\
\hline $\begin{array}{c}\text { Vertical } \\
\text { integration }\end{array}$ & Trade & 19 \\
\hline $\begin{array}{c}\text { Downstream } \\
\text { activities }\end{array}$ & Trade & 13 \\
\hline $\begin{array}{l}\text { Upstream } \\
\text { activities }\end{array}$ & Trade & 12 \\
\hline Knowledge & Spillovers & 166 \\
\hline Knowledge & Innovation & 166 \\
\hline Education & $\begin{array}{l}\text { Employment } \\
\text { (total) }\end{array}$ & 45 \\
\hline ICT capital & Innovation & 9 \\
\hline ICT capital & $\begin{array}{l}\text { Intangible } \\
\text { investment }\end{array}$ & 9 \\
\hline ICT capital & Knowledge & 7 \\
\hline ICT capital & Trade & 7 \\
\hline Internet & Knowledge & 7 \\
\hline Labor mobility & Spillovers & 31 \\
\hline Migration & Convergence & 29 \\
\hline Migration & $\begin{array}{c}\text { Geographic } \\
\text { location }\end{array}$ & 26 \\
\hline Labor mobility & Knowledge & 26 \\
\hline Innovation & Knowledge & 166 \\
\hline Innovation & Spillovers & 63 \\
\hline
\end{tabular}




\begin{tabular}{|c|c|c|}
\hline Sub-code 1 & Sub-code 2 & $\begin{array}{c}\text { Coun } \\
\mathbf{t}\end{array}$ \\
\hline Innovation & Trade & $\mathbf{6 0}$ \\
\hline $\begin{array}{c}\text { Geographic } \\
\text { location }\end{array}$ & Trade & $\mathbf{7 0}$ \\
\hline $\begin{array}{c}\text { Geographic } \\
\text { location }\end{array}$ & $\begin{array}{c}\text { Employment } \\
\text { (total) }\end{array}$ & $\mathbf{4 5}$ \\
\hline Convergence & Trade & $\mathbf{3 8}$ \\
\hline
\end{tabular}

Source: Own preparation.

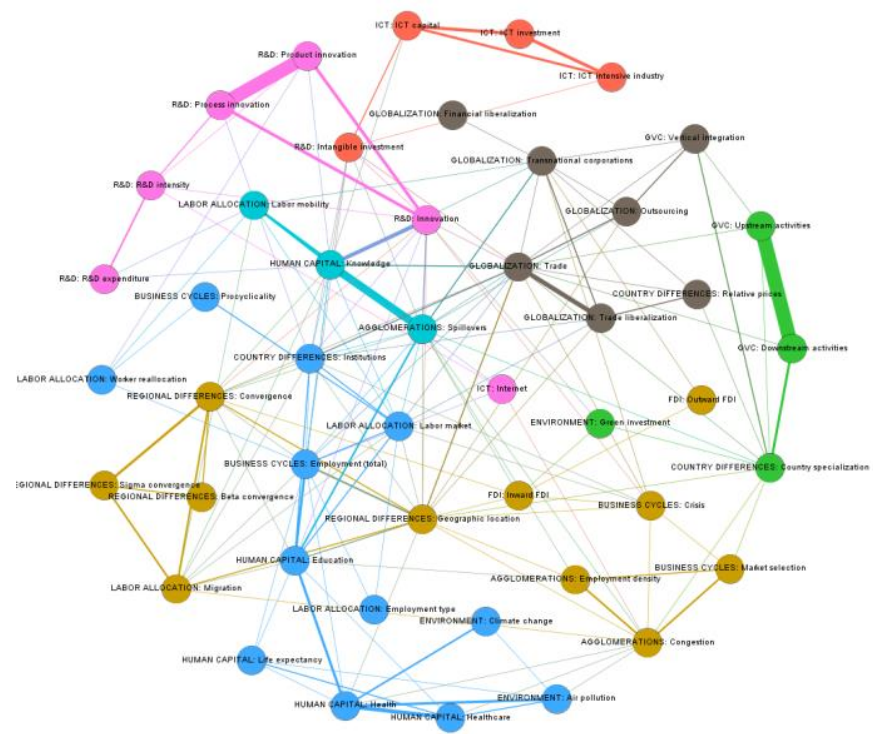

Fig. 8: Network view: overview

Source: Own preparation.

\section{Discussion and Conclusions}

Our study aimed to answer three key research questions. [RQ1] What are the key recent insights in the literature? [RQ2] Are there significant themes in the literature? [RQ3] Which factor is the most prominent in the literature?

When answering the first two questions, it should be noted that during the study we identified twelve areas related to various factors influencing labor productivity. Among the identified factors influencing labor productivity we have identified and categorized such factors like: (i) agglomerations effect; (ii) business cycles and market selection; (iii) country differences; (iv) environmental aspects; (v) foreign direct investment (FDI); (vi) globalization and international trade; (vii) global value chains (GVC); (viii) human capital; (ix) information and communications technology (ICT); (x) labor allocation; (xi) R\&D and innovation; (xii) regional differences.

Summarizing the analysis of these factors, it should be pointed out that for each of them the impact is differentiated and sometimes conditional and dependent on other factors. Agglomerations effect (i) has a strong positive impact on labor productivity, but it may be negative if there is a problem of congestion. Moreover, agglomeration may contribute to greater economic inequality. The impact of business cycle (ii) on labor productivity in short-run perspective is procyclical (negative during a recession, positive during expansion), however, the actual impact on labor productivity depends on the industry/market or the level of analysis (plant versus general economy). In the long-run perspective, a recession may foster creative destruction which causes the j-curve effect related to the entry of new companies on the market, i.e. initially productivity drops and then begins to rise. This effect is biggest when established firms experience productivity renewal. There are many institutional differences (iii) affecting the differences in productivity between countries. Innovation and most productive firms are heavily localized and occur mostly in developed economies with high capital intensity and strong institutional frameworks. Environmental (iv) impact on labor productivity aspects represented by climate change will most likely have to be strong and negative, especially in regions where agriculture is dominant, and in some vulnerable sectors like the construction industry. However, green investments may have a positive impact on labor productivity. In the case of foreign direct investment (v), inward FDI has a generally positive impact on labor, however, it depends on the development level of the receiving country, types of linkages, type of production, duration, regional aspects, and industry strength. The impact of outward FDI on labor productivity is positive. Globalization and international trade (vi) have a positive impact on manufacturing labor productivity in developing countries is accompanied by reforms aimed at changes in ownership concentration, and - in case of liberalization of trade in services - a positive impact on manufacturing labor productivity when manufacturers benefit from using these services. Exporting, cross-border acquisitions, outsourcing, and offshoring have a positive impact on labor productivity. Labor productivity gains from participation in global value chains (vii) are higher in developed countries than in developing countries. Similarly, the labor productivity of people with higher education grows more as a result of participation in the GVC than that of people with lower education. Clusters and multinational enterprises are crucial for GVC formation. Human capital (viii) has a strong positive impact on labor productivity. Knowledge spillovers help regional growth, which is most noticeable with close geographic proximity between urban areas. Investment in ICT capital (ix) has a positive impact on labor productivity, more so than in non-ICT 
capital. Digitalization and access to information made possible by the Internet make it a tool for regional convergence and inclusivity. Skilled labor mobility ( $\mathrm{x}$ ) has a positive impact on the manufacturing productivity of the receiving industry, especially in the case of employment in the high-tech sectors. Labor unions have a positive impact on manufacturing labor productivity. $R \& D$ and innovation (xi) have a very strong positive impact on labor productivity for both manufacturing and services. The impact of innovation intensity on labor productivity follows a U-curve. In the regional dimension (xii), economies experience fairly persistent interregional differences in labor productivity. On a regional level, there are two equilibria in regional productivity growth, with high-productivity regions converging in the center of Europe, and low-productivity regions converging in the peripheries. The polarization was present in the regional labor productivity of the European Union. Historically, the productivity levels across regions in the United States have been highly differentiated, while in Russia they have converged. China's East Rim provinces have had higher labor productivity and labor productivity growth than the rest of the country. In the past, the labor surplus in agriculture in China was high and unevenly spread between regions. Key recent insights from the above review concern the observed growing importance of global value chains and the impact of environmental and climate change factors.

The main limitation of this study is that it has not yet captured the impact of COVID-19 on labor productivity. Although we believe it may be partially internalized by the codes describing the business cycle and the development of global value chains, the full long-term impact of the pandemic is still unknown as of the writing of this article. However, these areas certainly require further and more in-depth exploration in future research. Another potential direction of future research could be a qualitative and quantitative text analysis of the differences present in literature published in different languages.

When analyzing significant themes in the literature, it is necessary to indicate the intensity of relationships between the identified research areas or factors. The network analysis allowed for the estimation of co-occurrence and c-coefficient indicators (see: network visualizations: Fig. 6 and

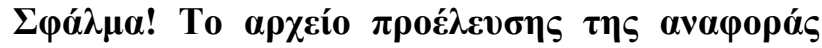

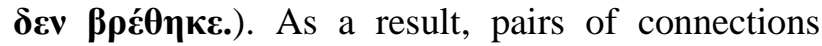
within the network were identified, which then form the key links of the areas. Among closely related pairs, one should mention: (i) agglomerations + (viii) human capital; (i) agglomerations + (v) FDI; (viii) human capital + (xi) R\&D; (vi) globalization + (vii) GVC; (i) agglomerations + (x) labor allocation; and (i) agglomerations + (xi) R\&D. These connections may indicate a strong correlation between the discussed factors. This is especially true for agglomerations which are linked to human capital, foreign investment, workforce allocation, and research and development. All these factors are part of the agglomeration phenomenon. The strong links between human capital and $R \& D$ are not surprising either, as high-quality human capital is essential for research development. Similarly, strong relationships between globalization and GVC are quite obvious.

The assessment of the most prominent factors in the literature to evaluate these factors is based on two criteria: quotes count and the above-mentioned co-occurrence and c-coefficient. When it comes to the quotes count, the most prominent factor is (xi) $\mathrm{R} \& \mathrm{D}$, followed by (vi) globalization and (viii) human capital. When it comes to the co-occurrence and c-coefficient, the most prominent factor is (viii) human capital, closely followed by (i) agglomerations, then either (xi) R\&D or (vi) globalization. Network analysis reveals two communities, the bigger one centered around (i) agglomerations, and the smaller one centered around (vi) globalization.

\section{References:}

[1] Snyder, H., Literature review as a research methodology: An overview and guidelines. Journal of Business Research 2019, 104, 333-339.

[2] Kuckartz, U., Qualitative text analysis: a guide to methods, practice \& using software, SAGE, Los Angeles 2014.

[3] Cai, F., Wang, D., Du, Y., Regional disparity and economic growth in China: The impact of labor market distortions. China Economic Review 2002, 13, 197212.

[4] Constantinescu, C., Mattoo, A., Ruta, M., Does vertical specialisation increase productivity? World Econ 2019, 42, 2385-2402.

[5] Dietzenbacher, E., Hoen, A.R., Los, B., Labor productivity in Western Europe 1975-1985: an intercountry, interindustry analysis. Journal of Regional Science 2000, 40, 425-452. 
[6] Eurostat, Glossary. 2020.

[7] Hatzikian, Y., Exploring the link between innovation and firm performance. J Knowl Econ 2015, 6, 749-768.

[8] Lemos, S., A survey of the effects of the minimum wage on prices. $J$ Economic Surveys 2008, 22, 187-212.

[9] McGowan, M.A., Andrews, D., Millot, V., The walking dead? Zombie firms and productivity performance in OECD countries. OECD Economic Department Working Papers 2017, No. 1372.

[10] Mohnen, P., Hall, B.H., Innovation and productivity: an update. Eurasian Business Review 2013, 3, 47-65.

[11] OECD, Glossary of Statistical Terms. 2020.

[12] Ortega-Argilés, R., The transatlantic productivity gap: a survey of the main causes: the transatlantic productivity gap. Journal of Economic Surveys 2012, 26, 395-419.

[13] Andersson, M., Lööf, H., Agglomeration and productivity: evidence from firm-level data. Ann Reg Sci 2011, 46, 601-620.

[14] Lööf, H., Johansson, B., R\&D strategy, metropolitan externalities and productivity: evidence from Sweden. Industry and Innovation 2014, 21, 141154.

[15] Broersma, L., Oosterhaven, J., Regional labor productivity in the Netherlands: evidence of agglomeration and congestion effects. Journal of Regional Science 2009, 49, 483-511.

[16] Rizov, M., Oskam, A., Walsh, P., Is there a limit to agglomeration? Evidence from productivity of Dutch firms. Regional Science and Urban Economics 2012, 42, 595-606.

[17] Di Giacinto, V., Gomellini, M., Micucci, G., Pagnini, M., Mapping local productivity advantages in Italy: industrial districts, cities or both? Journal of Economic Geography 2014, 14, 365-394.
[18] Fan, J., Industrial agglomeration and difference of regional productivity. Front. Econ. China 2007, 2, 346-361.

[19] Ke, S., Agglomeration, productivity, and spatial spillovers across Chinese cities. Ann Reg Sci 2010, 45, 157-179.

[20] Meijers, E.J., Burger, M.J., Spatial structure and productivity in US metropolitan areas. Environ Plan A 2010, 42, 1383-1402.

[21] Rigby, D.L., Essletzbichler, J., Agglomeration economies and productivity differences in US cities. Journal of Economic Geography 2002, 2, 407-432.

[22] Schumpeter, J.A., Capitalism, socialism and democracy, Routledge, New York, NY 2003.

[23] Archibugi, D., Filippetti, A., Frenz, M., Economic crisis and innovation: Is destruction prevailing over accumulation? Research Policy 2013, 42, 303-314.

[24] Archibugi, D., Filippetti, A., Frenz, M., The impact of the economic crisis on innovation: Evidence from Europe. Technological Forecasting and Social Change 2013, 80, 1247-1260.

[25] Devece, C., Peris-Ortiz, M., RuedaArmengot, C., Entrepreneurship during economic crisis: Success factors and paths to failure. Journal of Business Research 2016, 69, 5366-5370.

[26] van Ark, B., Jäger, K., Recent trends in Europe's output and productivity growth performance at the sector level,. International Productivity Monitor 2017, 33, 8-23.

[27] Melitz, M.J., Polanec, S., Dynamic Olley-Pakes productivity decomposition with entry and exit. The RAND Journal of Economics 2015, 46, 362-375.

[28] Hyytinen, A., Maliranta, M., Firm lifecycles and evolution of industry productivity. Research Policy 2013, 42, 1080-1098.

[29] Dosi, G., Grazzi, M., Tomasi, C., Zeli, A., Turbulence underneath the big calm? The micro-evidence behind Italian 
productivity dynamics. Small Bus Econ 2012, 39, 1043-1067.

[30] Baily, M.N., Bartelsman, E.J., Haltiwanger, J., Labor productivity: structural change and cyclical dynamics. Review of Economics and Statistics 2001, 83, 420-433.

[31] Burda, M.C., Hamermesh, D.S., Stewart, J., Cyclical Variation in Labor Hours and Productivity Using the ATUS. American Economic Review 2013, 103, 99-104.

[32] Galí, J., van Rens, T., The vanishing procyclicality of labor productivity. Warwick Economic Research Papers 2014, No. 1061.

[33] Gal, P.N., Measuring total factor productivity at the firm level using OECD-ORBIS. OECD Economics Department Working Papers 2013, No. 1040.

[34] Timmer, M.P., Los, B., Localized innovation and productivity growth in Asia: an intertemporal DEA approach. $J$ Prod Anal 2005, 23, 47-64.

[35] Dollar, D., Wolff, E.N., Covergence of industry labor productivity among advanced economies, 1963-1982. The Review of Economics and Statistics 1988, 70, 549.

[36] Canzoneri, M.B., Cumby, R.E., Diba, B., Relative labor productivity and the real exchange rate in the long run: evidence for a panel of OECD countries. Journal of International Economics 1999, 47, 245-266.

[37] Crinò, R., Wages, skills, and integration in Poland, Hungary and the Czech Republic: an industry-level analysis. Transition Stud Rev 2005, 12, 432-459.

[38] Crespi, F., Pianta, M., Diversity in innovation and productivity in Europe. $J$ Evol Econ 2008, 18, 529-545.

[39] Li, T., Liu, H., Salvo, A., Severe air pollution and labor productivity. SSRN Journal 2015, No. 8916.

[40] He, J., Liu, H., Salvo, A., Severe air pollution and labor productivity: evidence from industrial towns in China.
American Economic Journal: Applied Economics 2019, 11, 173-201.

[41] Lanzi, E., Dellink, R., Chateau, J., The sectoral and regional economic consequences of outdoor air pollution to 2060. Energy Economics 2018, 71, 89113.

[42] Kjellstrom, T., Kovats, R.S., Lloyd, S.J., Holt, T., et al., The direct impact of climate change on regional labor productivity. Archives of Environmental \& Occupational Health 2009, 64, $217-$ 227.

[43] Altinsoy, H., Yildirim, H.A., Labor productivity losses over western Turkey in the twenty-first century as a result of alteration in WBGT. Int $J$ Biometeorol 2015, 59, 463-471.

[44] Li, X., Chow, K.H., Zhu, Y., Lin, Y., Evaluating the impacts of hightemperature outdoor working environments on construction labor productivity in China: A case study of rebar workers. Building and Environment 2016, 95, 42-52.

[45] Yi, W., Chan, A., Effects of heat stress on construction labor productivity in Hong Kong: a case study of rebar workers. IJERPH 2017, 14, 1055-1069.

[46] Woo, C., Chung, Y., Chun, D., Han, S., et al., Impact of green innovation on labor productivity and its determinants: an analysis of the Korean manufacturing industry. Bus. Strat. Env. 2014, 23, 567576.

[47] Leiter, A.M., Parolini, A., Winner, H., Environmental regulation and investment: Evidence from European industry data. Ecological Economics 2011, 70, 759-770.

[48] Marin, G., Mazzanti, M., The evolution of environmental and labor productivity dynamics: Sector based evidence from Italy. J Evol Econ 2013, 23, 357-399.

[49] Simas, M., Wood, R., Hertwich, E., Labor embodied in trade: the role of labor and energy productivity and implications for greenhouse gas emissions. Journal of Industrial Ecology 2015, 19, 343-356. 
[50] Vahter, P., Does FDI spur productivity, knowledge sourcing and innovation by incumbent firms? Evidence from manufacturing industry in Estonia. The World Economy 2011, 34, 1308-1326.

[51] Jabbour, L., Mucchielli, J.L., Technology transfer through vertical linkages: the case of the Spanish manufacturing industry. Journal of Applied Economics 2007, 10, 115-136.

[52] Blomstrom, M., Kokko, A., Multinational Corporations and Spillovers. J Economic Surveys 1998, 12, 247-277.

[53] Mullen, J.K., Williams, M., Foreign direct investment and regional productivity spillovers in US manufacturing. Review of Urban \& Regional Development Studies 2007, 19, 185-196.

[54] Bijsterbosch, M., Kolasa, M., FDI and productivity convergence in Central and Eastern Europe: an industry-level investigation. Review of World Economics 2010, 145, 689-712.

[55] Antonescu, D., Empirical analysis of foreign direct investments at NUTS 2 region, in European Union and Romania. Procedia Economics and Finance 2015, 22, 681-689.

[56] Zhou, D., Li, S., Tse, D.K., The impact of FDI on the productivity of domestic firms: the case of China. International Business Review 2002, 11, 465-484.

[57] Zhu, G., Tan, K.Y., Foreign direct investment and labor productivity: New evidence from China as the host. Thunderbird International Business Review 2000, 42, 507-528.

[58] Boghean, C., State, M., The relation between foreign direct investments (FDI) and labour productivity in the European Union countries. Procedia Economics and Finance 2015, 32, 278285.

[59] Fariñas, J.C., Martín-Marcos, A., Exporting and economic performance: firm- level evidence of Spanish manufacturing. World Economy 2007, 30, 618-646.
[60] Wagner, J., The causal effects of exports on firm size and labor productivity: first evidence from a matching approach. Economics Letters 2002, 77, 287-292.

[61] Ramstetter, E.D., Labor productivity, wages, nationality, and foreign ownership shares in Thai manufacturing, 1996-2000. Journal of Asian Economics 2004, 14, 861-884.

[62] Siedschlag, I., Zhang, X., Internationalisation of firms and their innovation and productivity. Economics of Innovation and New Technology 2015, 24, 183-203.

[63] Bottazzi, G., Grazzi, M., Dynamics of productivity and cost of labour in Italian manufacturing firms. Bulletin of Economic Research 2014, 66, S55-S73.

[64] Cincera, M., Ravet, J., Globalisation, industrial diversification and productivity growth in large European R\&D companies. J Prod Anal 2014, 41, 227-246.

[65] Du, J., Temouri, Y., High-growth firms and productivity: evidence from the United Kingdom. Small Bus Econ 2015, 44, 123-143.

[66] Parteka, A., Wolszczak-Derlacz, J., The impact of trade integration with the European Union on productivity in a posttransition economy: the case of Polish manufacturing sectors. Emerging Markets Finance and Trade 2013, 49, 84-104.

[67] Paus, E., Reinhardt, N., Robinson, M., Trade liberalization and productivity growth in Latin American manufacturing, 1970-98. The Journal of Policy Reform 2003, 6, 1-15.

[68] Gehringer, A., Uneven effects of financial liberalization on productivity growth in the EU: Evidence from a dynamic panel investigation. International Journal of Production Economics 2015, 159, 334-346.

[69] Beverelli, C., Fiorini, M., Hoekman, B., Services trade policy and manufacturing productivity: The role of institutions. Journal of International Economics 2017, 104, 166-182. 
[70] Baghdasaryan, D., la Cour, L., Competition, ownership and productivity. A panel analysis of Czech firms. Journal of Economics and Business 2013, 69, 86-100.

[71] McCaig, B., Pavcnik, N., Export markets and labor allocation in a lowincome country. American Economic Review 2018, 108, 1899-1941.

[72] Katz, J., Structural change and labor productivity growth in Latin American manufacturing industries 1970-96. World Development 2000, 28, 15831596.

[73] Fariñas, J.C., López, A., Martín-Marcos, A., Assessing the impact of domestic outsourcing and offshoring on productivity at the firm level. Applied Economics 2014, 46, 1814-1828.

[74] Girma, S., Gorg, H., Outsourcing, foreign ownership, and productivity: evidence from UK establishment- level data. Rev International Economics 2004, 12, 817-832.

[75] Egger, H., Egger, P., International outsourcing and the productivity of low- skilled labor in the EU. Economic Inquiry 2006, 44, 98-108.

[76] Bertrand, O., Capron, L., Productivity enhancement at home via cross-border acquisitions: The roles of learning and contemporaneous domestic investments: Cross-Border Acquisitions and Domestic Productivity. Strat. Mgmt. J. 2015, 36, 640-658.

[77] Hagemejer, J., Trade and growth in the new member states: the role of global value chains. Emerging Markets Finance and Trade 2018, 54, 26302649.

[78] Kummritz, V., Do global value chains cause industrial development? CTEI Working Paper 2016, No. 2016-01.

[79] Pahl, S., Timmer, M.P., Do global value chains enhance economic upgrading? A long view. The Journal of Development Studies 2020, 56, 1683-1705.

[80] Criscuolo, C., Timmis, J., The relationship between global value chains and productivity. International Productivity Monitor 2017, 61-83.

[81] Anderson, E.G., Fine, C.H., Parker, G.G., Upstream volatility in the supply chain: the machine tool industry as a case study. Production and Operations Management 2000, 9, 239-261.

[82] Cainelli, G., Ganau, R., Giunta, A., Spatial agglomeration, global value chains, and productivity. Microevidence from Italy and Spain. Economics Letters 2018, 169, 43-46.

[83] Antràs, P., Gortari, A., On the geography of global value chains. ECTA 2020, 88, 1553-1598.

[84] Kummritz, V., Taglioni, D., Winkler, D., Economic upgrading through global value chain participation: which policies increase the value added gains? Policy Research Working Paper 2017, No. 8007.

[85] Wang, Z., Wei, S.-J., Yu, X., Zhu, K., Characterizing global value chains: production length and upstreamness. NBER Working Paper Series 2017, No. w23261.

[86] Degain, C., Meng, B., Wang, Z., Recent trends in global trade and global value chains, in: Global Value Chain Development Report 2017: Measuring and Analyzing the Impact of GVCs On Economic Development, Word Bank, 2017, pp. 37-68.

[87] Gereffi, G., Luo, X., Risks and opportunities of participation in global value chains. JBFE 2015, 2, 51-63.

[88] Strange, R., Zucchella, A., Industry 4.0, global value chains and international business. Multinational Business Review 2017, 25, 174-184.

[89] Choi, N., Global value chains and East Asian trade in value-added. Asian Economic Papers 2015, 14, 129-144.

[90] Rodrik, D., New technologies, global value chains, and developing economies. NBER Working Paper Series 2018, No. w25164.

[91] Nadvi, K., Thoburn, J.T., Thang, B.T., Ha, N.T.T., et al., Vietnam in the global garment and textile value chain: impacts 
on firms and workers. J. Int. Dev. 2004, 16, 111-123.

[92] Barrientos, S., Kritzinger, A., Squaring the circle: global production and the informalization of work in South African fruit exports. J. Int. Dev. 2004, 16, 81-92.

[93] Chansarn, S., Labor productivity growth, education, health and technological progress: a cross-country analysis. Economic Analysis and Policy 2010, 40, 249-261.

[94] Benos, N., Karagiannis, S., Do education quality and spillovers matter? Evidence on human capital and productivity in Greece. Economic Modelling 2016, 54, 563-573.

[95] Li, H., Loyalka, P., Rozelle, S., Wu, B., Human capital and China's future growth. Journal of Economic Perspectives 2017, 31, 25-48.

[96] Fafchamps, M., Quisumbing, A.R., Human capital, productivity, and labor allocation in rural Pakistan. The Journal of Human Resources 1999, 34, 369.

[97] Berumen, S.A., Pérez-Megino, L.P., Ibarra, K.A., Extrinsic motivation index: A new tool for managing labor productivity. International Journal of Business Science \& Applied Management 2016, 11, 1-17.

[98] Iverson, R.D., Zatzick, C.D., The effects of downsizing on labor productivity: The value of showing consideration for employees' morale and welfare in highperformance work systems. Hum. Resour. Manage. 2011, 50, 29-44.

[99] Koch, M.J., McGrath, R.G., Improving labor productivity: Human resource management policies do matter. Strategic Management Journal 1996, 17, 335-354.

[100] Fischer, M.M., Scherngell, T., Reismann, M., Knowledge spillovers and total factor productivity: evidence using a spatial panel data model: knowledge spillovers and total factor productivity. Geographical Analysis 2009, 41, 204-220.
[101] Fischer, M.M., Bartkowska, M., Riedl, A., Sardadvar, S., et al., The impact of human capital on regional labor productivity in Europe. Lett Spat Resour Sci 2009, 2, 97-108.

[102] Fuchs-Schündeln, N., Izem, R., Explaining the low labor productivity in East Germany - A spatial analysis. Journal of Comparative Economics 2012, 40, 1-21.

[103] Fan, S., Gulati, A., Thorat, S., Investment, subsidies, and pro-poor growth in rural India. Agricultural Economics 2008, 39, 163-170.

[104] Stack, M.L., Ozawa, S., Bishai, D.M., Mirelman, A., et al., Estimated economic benefits during the 'decade of vaccines' include treatment savings, gains in labor productivity. Health Affairs 2011, 30, 1021-1028.

[105] Cabral, R., Mollick, A.V., Saucedo, E., Violence in Mexico and its effects on labor productivity. Ann Reg Sci 2016, 56, 317-339.

[106] Craig, B.J., Pardey, P.G., Roseboom, J., International productivity patterns: accounting for input quality, infrastructure, and research. American Journal of Agricultural Economics 1997, 79, 1064-1076.

[107] Strauss, J., Does better nutrition raise farm productivity? Journal of Political Economy 1986, 94, 297-320.

[108] Belorgey, N., Lecat, R., Maury, T., Determinants of productivity per employee: An empirical estimation using panel data. SSRN Journal 2004, No. 110.

[109] Kilıçaslan, Y., Sickles, R.C., Atay Kayış, A., Üçdoğruk Gürel, Y., Impact of ICT on the productivity of the firm: evidence from Turkish manufacturing. $J$ Prod Anal 2017, 47, 277-289.

[110] Nurmilaakso, J.-M., ICT solutions and labor productivity: evidence from firmlevel data. Electron Commer Res 2009, 9, 173-181.

[111] Piatkowski, M., The contribution of ICT investment to economic growth and 
labor productivity in Poland 1995-2000. SSRN Journal 2003, No. 43.

[112] Bergeaud, A., Cette, G., Lecat, R., Productivity trends in advanced countries between 1890 and 2012 . Review of Income and Wealth 2016, 62, 420-444.

[113] Jung, J., López-Bazo, E., On the regional impact of broadband on productivity: The case of Brazil. Telecommunications Policy 2019.

[114] Eicher, T.S., Roehn, O., Sources of the German productivity demise: tracing the effects of industry- level information and communication technology investment. German Economic Review 2007, 8, 211-236.

[115] Acemoglu, D., Autor, D., Dorn, D., Hanson, G.H., et al., Return of the Solow Paradox? IT, productivity, and employment in US manufacturing. American Economic Review 2014, 104, 394-399.

[116] Foster-McGregor, N., Pöschl, J., Productivity effects of knowledge transfers through labour mobility. $J$ Prod Anal 2016, 46, 169-184.

[117] Stoyanov, A., Zubanov, N., Productivity spillovers across firms through worker mobility. American Economic Journal: Applied Economics 2012, 4, 168-198.

[118] Lentz, R., Mortensen, D.T., Productivity growth and worker reallocation. Int Economic Rev 2005, 46, 731-749.

[119] Fischer, L.B., Pfaffermayr, M., The more the merrier? Migration and convergence among European regions. Regional Science and Urban Economics 2018, 72, 103-114.

[120] Mefford, R.N., The effect of unions on productivity in a multinational manufacturing firm. ILR Review 1986, 40, 105-114.

[121] Lisi, D., The impact of temporary employment and employment protection on labour productivity: evidence from an industry-level panel of EU countries. J Labour Market Res 2013, 46, 119144.
[122] Bardazzi, R., Duranti, S., Atypical work: a threat to labour productivity growth? Some evidence from Italy. International Review of Applied Economics 2016, 30 , 620-643.

[123] Vergeer, R., Kleinknecht, A., The impact of labor market deregulation on productivity: a panel data analysis of 19 OECD countries (1960-2004). Journal of Post Keynesian Economics 2010, 33, 371-408.

[124] Tridico, P., Pariboni, R., Inequality, financialization, and economic decline. Journal of Post Keynesian Economics 2018, 41, 236-259.

[125] Carter, S., Real wage productivity elasticity across advanced economies, 1963-1996. Journal of Post Keynesian Economics 2007, 29, 573-600.

[126] Baily, M.N., Bartelsman, E.J., Haltiwanger, J., Downsizing and productivity growth: myth or reality? Small Bus Econ 1996, 8, 259-278.

[127] Haynes, K.E., Dinc, M., Productivity Change in Manufacturing Regions: A Multifactor/Shift-Share Approach. Growth and Change 1997, 28, 201-221.

[128] Apergis, N., Economidou, C., Filippidis, I., Innovation, technology transfer and labor productivity linkages: evidence from a panel of manufacturing industries. Rev World Econ 2008, 144, 491-508.

[129] Baumann, J., Kritikos, A.S., The link between R\&D, innovation and productivity: Are micro firms different? Research Policy 2016, 45, 1263-1274.

[130] Chudnovsky, D., López, A., Pupato, G., Innovation and productivity in developing countries: A study of Argentine manufacturing firms' behavior (1992-2001). Research Policy 2006, 35, 266-288.

[131] Crespi, G., Zuniga, P., Innovation and productivity: evidence from six Latin American countries. SSRN Journal 2010, No. IDB-WP-218.

[132] De Fuentes, C., Dutrenit, G., Santiago, F., Gras, N., Determinants of Innovation and Productivity in the Service Sector in 
Mexico. Emerging Markets Finance and Trade 2015, 51, 578-592.

[133] Lee, D., Role of R\&D in the productivity growth of Korean industries: Technology gap and business cycle. Journal of Asian Economics 2016, 45, 31-45.

[134] Piras, G., Postiglione, P., Aroca, P., Specialization, R\&D and productivity growth: evidence from EU regions. Ann Reg Sci 2012, 49, 35-51.

[135] Sondermann, D., Productivity in the euro area: any evidence of convergence? Empir Econ 2014, 47, 999-1027.

[136] Boix-Domenech, R., Soler-Marco, V., Creative service industries and regional productivity: CSI and the productivity of the regions. Papers in Regional Science 2017, 96, 261-279.

[137] Coad, A., Pellegrino, G., Savona, M., Barriers to innovation and firm productivity. Economics of Innovation and New Technology 2016, 25, 321334.

[138] Borgo, M.D., Goodridge, P., Haskel, J., Pesole, A., Productivity and growth in UK industries: an intangible investment approach. Oxford Bulletin of Economics and Statistics 2013, 75, 806-834.

[139] Niebel, T., O’Mahony, M., Saam, M., The contribution of intangible assets to sectoral productivity growth in the EU. Review of Income and Wealth 2017, 63, S49-S67.

[140] Roth, F., Thum, A.-E., Intangible capital and labor productivity growth: Panel evidence for the EU from 1998-2005. Review of Income and Wealth 2013, 59, 486-508.

[141] Hall, B., Innovation and productivity. NBER Working Paper Series 2011, No. w17178, w17178.

[142] Galenson, W., Leibenstein, H., Investment criteria, productivity, and economic development. The Quarterly Journal of Economics 1955, 69, 343.

[143] Travaglini, G., Trade-off between labor productivity and capital accumulation in Italian energy sector. Journal of Policy Modeling 2012, 34, 35-48.
[144] Waldinger, F., Bombs, brains, and science: the role of human and physical capital for the creation of scientific knowledge. Review of Economics and Statistics 2016, 98, 811-831.

[145] Paci, R., More similar and less equal: Economic growth in the European regions. Weltwirtschaftliches Archiv 1997, 133, 609-634.

[146] Fotopoulos, G., European union regional productivity dynamics: a "distributional" approach. J Regional Sci 2008, 48, 419-454.

[147] Basile, R., Productivity polarization across regions in Europe: the role of nonlinearities and spatial dependence. International Regional Science Review 2009, 32, 92-115.

[148] Cuadrado-Roura, J.R., García-Greciano, B., Raymond, J.L., Regional convergence in productivity and productive structure: The Spanish case. International Regional Science Review 1999, 22, 35-53.

[149] Dall'erba, S., Productivity convergence and spatial dependence among Spanish regions. J Geograph Syst 2005, 7, 207227.

[150] Mikheeva, N.N., Comparative analysis of labor productivity in Russian regions. Reg. Res. Russ. 2016, 6, 105-114.

[151] Bernard, A.B., Jones, C.I., Productivity and convergence across U.S. States and industries. Empirical Economics 1996, 21, 113-135.

[152] Hulten, C.R., Schwab, R.M., Regional productivity growth in US manufacturing: 1951-78. The American Economic Review 1984, 74, 152-162.

[153] Bhattacharyya, A., Parker, E., Labor productivity and migration in Chinese agriculture A stochastic frontier approach. China Economic Review 1999, 10, 59-74.

[154] Jiang, X., Dietzenbacher, E., Los, B., A dissection of the growth of regional disparities in Chinese labor productivity between 1997 and 2002. Ann Reg Sci 2014, 52, 513-536. 
[155] Yang, L., Lahr, M.L., Labor productivity differences in China 19871997: an interregional decomposition analysis. The Review of Regional Studies 2008, 38, 319-341.

[156] Web of Science, Database. 2020.

Contribution of Individual Authors to the Creation of a Scientific Article (Ghostwriting Policy)

Both authors have contributed equally to the creation of this scientific article.

Sources of Funding for Research Presented in a Scientific Article or Scientific Article

\section{Itself}

This research received funding within the framework of statutory research of the Collegium of World Economy, SGH School of Economics.

Creative Commons Attribution License 4.0 (Attribution 4.0 International, CC BY 4.0)

This article is published under the terms of the Creative Commons Attribution License 4.0 https://creativecommons.org/licenses/by/4.0/deed.en _US 